\title{
KUPOPRODAJA UZ PRIDRŽAJ BOLJEG KUPCA (IN DIEM ADDICTIO) U RIMSKOJ PRAVNOJ TRADICIJI
}

Sažetak:

U radu je prikazan in diem addictio, uglavak o kupoprodaji uz pridržaj boljeg kupca rimskoga prava, uz analizu niza odredaba iz Digesta koje se odnose na ovaj uglavaki njegovu primjenu. Posebna pozornost je posvećena problemu što je to "bolja ponuda" te kakva prava i obveze ona stvara za ugovorne strane. U drugom dijelu rada obrađene su mogućnosti ugovaranja ovog uglavka u izabranim suvremenim pravnim porecima - francuskom, austrijskom, njemačkom i hrvatskom. Zaključuje se da uz posebno uređenje u austrijskom pravu i drugi pravni poreci sadrže temelje za ugovaranje kupoprodaje uz pridržaj boljeg kupca i u obliku odgodnog i raskidnog uvjeta.

Ključne riječi: $\quad$ kupoprodaja, emptio venditio, in diem addictio, uglavak o kupoprodaji uz pridržaj boljeg kupca, rimsko pravo

\section{UVOD}

Ugovor o kupoprodaji (emptio venditio) bio je od iznimne važnosti u rimskom pravu, ${ }^{1}$ kao što zauzima istaknuto mjesto i u suvremenom pravu. ${ }^{2}$ Pri tome, osnovne konture i pravila,

* Dr. sc. Tomislav Karlović, izvanredni profesor Pravnog fakulteta Sveučilišta u Zagrebu, Ćirilometodska 4, 10000 Zagreb, Republika Hrvatska. Adresa e-pošte: tkarlovi@pravo.hr. ORCID: http://orcid.org/0000-0003-1846-1318.

** Ivona Rapić, mag. iur., Rapić savjeti j.d.o.o., Augusta Cesarca 89, 44000 Sisak, Republika Hrvatska. Adresa e-pošte: irapi11@net. hr. ORCID: https://orcid.org/0000-0003-4806-2633.

1 Iz opširne literature o kupoprodaji u rimskom pravu vidi: De Zulueta, F., The Roman Law of Sale, Clarendon Press, Oxford, 1945. ; Arangio-Ruiz, V., La compravendita in diritto romano, E. Jovene, Napoli, 1954.; Daube, D. (ur.) Studies in the Roman Law of Sale. Dedicated to the memory of F. De Zulueta, Clarendon Press, Oxford, 1959.; Kaser, M., Das römische Privatrecht, I, Das altrömische, das vorklassische und klassische Recht, 2. izdanje, Beck'sche Verlagsbuchhandlung, München, 1971., str. 545. i sl.; Burdese, A., Vendita (diritto romano), u: Azara, A., Eula, E., (ur.) Novissimo digesto italiano, XX, Unione tipografico - Editrice Torinese, Torino, 1975., str. 594. i sl.; Petranović, A., Položaj kupca u pravnom režimu rimske kupoprodaje, doktorska disertacija, Zagreb, $1996 . ;$ Talamanca, M., Istituzioni di diritto romano, Giuffrè editore, Milano, 1990., str. 580. i sl.; Guarino, A., Diritto privato romano, 12. izdanje, Jovene, Napoli, 2001., str. 880. i sl. Također usp. Romac, A., Rimsko pravo, Narodne novine, Zagreb, 1994., str. 304. i sl.; Horvat, M., Rimsko pravo, Pravni fakultet Sveučilišta u Zagrebu, 1998., str. 268. i sl.

2 Primjerice, glede Republike Hrvatske, usp. Klarić, P., Vedriš, M., Građansko pravo, IX. izdanje, Narodne novine, Zagreb, 2006. str. 493. i sl. Za komparativno pravo usp. Huber, P., Comparative Sales Law, u: Reimann, M., Zimmermann, R., (ur.) The Oxford Handbook of Comparative Law, OUP, Oxford, 2006., str. 938.-966. 
kao i niz pojedinačnih rješenja, u hrvatskom pravu te nizu drugih pravnih sustava pripadnih kontinentalno-europskom pravnom krugu, vuku svoje porijeklo iz pravila rimskog prava o kupoprodaji. ${ }^{3}$ Od načina sklapanja, bitnih sastojaka, prava i obveza stranaka do posebnih uglavaka, u odredbama aktualnog hrvatskog Zakona o obveznim odnosima (dalje: ZOO 2005.) ${ }^{4}$ o kupoprodaji jasno se mogu identificirati značajke rimske kupoprodaje te rješenja pripadna rimskom pravu. Međutim, određeni aspekti ugovora su promijenjeni ili izostavljeni pri suvremenom uređenju instituta.

U ovom radu obrađen je jedan takav uglavak koji se ugovarao uz kupoprodaju u rimskom pravu, no koji nije našao svoje mjesto u hrvatskom ZOO-u 2005. Riječ je o in diem addictio, uglavku o kupoprodaji uz pridržaj boljeg kupca prema kojemu su učinci ugovora ovisili o uvjetovanoj okolnosti postavljanja bolje ponude od one koja je prvotno prihvaćena od strane prodavatelja pri sklapanju ugovora i njezina prihvata. ${ }^{5} \mathrm{Uz}$ analizu uređenja u rimskom pravu, $\mathrm{u}$ radu su izložena i komparativnopravna rješenja te je obrađena mogućnost ugovaranja i ostvarenja učinaka ovog uglavka u suvremenom hrvatskom pravu.

\section{IN DIEM ADDICTIO}

\subsection{POJAM I PRAVNI UČINCI UGLAVKA}

Ugovor o kupoprodaji je u rimskom pravu, za razliku od nekih suvremenih pravnih sustava, ${ }^{6}$ imao neposredno samo obveznopravni učinak. ${ }^{7}$ Njime bi nastajala za prodavatelja samo obveza prijenosa mirnog posjeda prodane stvari kupcu. Tek nakon što je bila izvršena predaja stvari, odnosno zahtijevana forma prijenosa vlasništva ovisno o povijesnom razdoblju, ako je prodavatelj bio vlasnik prodane stvari, dolazilo je do konačnog stjecanja vlasništva.

U određenim slučajevima, međutim, posebnim uglavkom dogovaralo se da stranke mogu naknadno učiniti kupoprodaju nevaljanom a da time otpadnu i njezini posredni učinci na području stvarnog prava. U domaćoj romanističkoj literaturi takve pogodbe se označavaju kao

3 Usp. Zimmermann, R., The Law of Obligations. Roman Foundations of the Civilian Tradition, Juta \& Co, Ltd., Kluwer, Deventer, Boston, Cambridge (MA), 1990., str. 230.

4 Zakon o obveznim odnosima, Narodne novine, broj 35/2005, 41/2008, 125/2011 i 78/2015

5 Općenito o ovom uglavku u rimskom pravu usp. Sieg, H., Quellenkritische Studien zur Bessergebotsklausel (in diem addictio) im römischen Kaufrecht, Friederichsen, de Gruyter \& Co. m.b.h., Hamburg, 1933.; Henle, R., Die rechtliche Natur der in diem addictio beim Kaufvertrage, u: Festschrift Paul Koschaker, II. Band., Böhlau, Weimar, str. 169.-192.; De Zulueta, op. cit. u bilj. 1, str. 55.-56.; Arangio-Ruiz, op. cit. u bilj. 1, str. 401.-402., 405.-429.; De Fontette, F., Recherches sur l' in diem addictio, u: Studi in onore Pietro De Francisci, vol. III., Giuffrè, Milano, 1956., str. 539.-555.; Romano, S., Addictio in diem, u: Azara, A., Eula, E., (ur.) Novissimo Digesto Italiano, Vol. I, Unione Tipografico, Torino, 1957., str. 280.-281.; Kaser, op. cit. u bilj. 1, str. 561.; Peters, F., Die Rücktrittsvorbehalte des römischen Kaufrechts, Böhlau Verlag, Köln, Wien, 1973., str. 7. i sl.; Romac, op. cit. u bilj. 1, str. 313.; Horvat, op. cit. u bilj. 1, str. 276.; Zimmermann, op. cit. u bilj. 3, str. 735.-737.; Guarino, op. cit. u bilj. 1, str. 900.-901.; Petranović, A., Uvjetovani konsenzus i rimska uvjetna kupoprodaja, Zbornik Pravnog fakulteta Sveučilišta u Rijeci, god. 28, br. 2, 2007., str. 1231.-1234.; Nicosia, E., In diem addictio e lex commissoria, Libreria Editrice Torre, Catania, 2013.; Pokecz Kovacs, A., Advantages and Disadvantages by the in diem addictio, u: Sturm, F.; Thomas, P.; Otto, J.; Mori, H., (ur.) Liber Amicorum Guido Tsuno, Vico Verlag, Frankfurt am Main, 2013., str. 317.

6 Riječ je o Francuskoj i zemljama koje prate tradiciju Code civilea prema kojemu samim ugovorom o kupoprodaji dolazi i do prijenosa vlasništva. Usp. Zimmermann, op. cit. u bilj. 3, str. 271. 
uglavci uz kupoprodaju sa stvarnopravnim učinkom, a to su bili lex commissoria (kupoprodaja uz pridržaj prava vlasništva) i in diem addictio (kupoprodaja uz pridržaj boljeg kupca). ${ }^{8} \mathrm{U}$ Digestama su obama uglavcima posvećeni zasebni naslovi, a dvadeset fragmenata uključenih u naslov o in diem addictio (D. 18.2.) upućuju na njegovu važnost, kao i na niz problema oko njegove primjene. Pri tome, može se istaknuti, rimski pravnici koncentrirali su se na pojedinačne probleme u koncepciji i primjeni instituta, međutim, nisu raspravljane njegove funkcije, npr. pri prodaji stvari na dražbama što bi, prema pretpostavkama romanista, trebalo biti važnije područje njegove uporabe. ${ }^{9}$

Temeljni primjer za in diem addictio dao je rimski pravnik Paulo prema čijem je tekstu D. 18.2.1 uglavak izgledao ovako: "Ovo zemljište neka ti bude prodano za sto (100) ako se do prvih sljedećih siječanjskih Kalenda ne pojavi netko drugi tko će dati povoljniju ponudu da bi stvar stekao od vlasnika". ${ }^{10}$ Iz fragmenta proizlazi da je ugovor sklopljen uz uvjet - ako kupac ne dobije bolju ponudu unutar točno određenog razdoblja. ${ }^{11}$ Ovaj izričaj, iako se u pogledu svrhe i uvjetovane okolnosti čini dosta jasan, skriva dilemu i ključni problem o kojem su se razvila suprotstavljena mišljenja među rimskim pravnicima. Naime, iz samog teksta nije vidljiva pravna narav uglavka, odnosno je li on imao učinke odgodnog (suspenzivnog) ili raskidnog (rezolutivnog) uvjeta što je bilo predmetom spora. Kako je Ulpijan iznio stavove svojih prethodnika u D. 18.2.2, prema jednoj skupini autora uzimalo bi se da je sklopljen bezuvjetan ugovor o kupoprodaji, no koji bi bio raskinut ispunjenjem uvjeta, emptio pura, est, sed sub condicione resolvitur, dok su zastupnici drugog stajališta tvrdili da je kupoprodaja bila sklopljena pod odgodnim uvjetom. ${ }^{12}$

Konkretnije, prema prvom mišljenju, za koje se smatra da ga je formulirao Julijan, ${ }^{13}$ s obzirom na ponovljene upute na ovog autora pri objašnjenju stava, smatralo se da je ugovor o kupoprodaji bio sklopljen pod raskidnim uvjetom, odnosno kako tumači dio doktrine, bez uvjeta, no uz istodobni dogovor, pactum, o raskidu u slučaju ispunjenja uvjeta. ${ }^{14}$ Kod ovog na-

$8 \quad$ Usp. Romac, op. cit. u bilj. 1, str. 312.-313.; Horvat, op. cit. u bilj. 1, str. 276. Kod drugih autora podjela se vrši prema drugim kriterijima, npr. kod Zuluete na uglavke u korist prodavatelja i one u korist kupca. Usp. de Zulueta, op. cit. u bilj. 1, str. 55. i sl. Protiv kategorizacije in diem addictio kao uzgrednog uglavka te njegova izjednačavanja s lex commissoria vidi Henle, op. cit. u bilj. 5, str. 171.-173.

9 Zbog izostanka jasnih naznaka primjene instituta u prodaji na dražbama u izvorima i kompleksnosti pitanja odnos in diem addictio i prodaje na dražbi, kako u rimskom pravu tako i u suvremenim pravnim sustavima, bit će zasebno obrađen. O pravnom uređenju privatne dražbe u rimskom pravu usp. Talamanca, M., Contributi allo studio delle vendite all'asta nel mondo classico, Atti Lincei, anno CCCLI., ser. VIII., vol. VI., fasc. 2., Roma, 1954.; Thielmann, G., Die römische Privatauktion, zugleich ein Beitrag zum römischen Bankierrecht, Duncker \& Humblot, Berlin, 1961.

10 Usp. De Fontette, op. cit. u bilj. 5, str. 543.; Thomas, J. A. C., Provisions for Calling Off a Sale, Tijdschrift voor Rechtsgeschiedenis, vol. 35, br. 4, 1967., str. 561.-562.; Pokecz Kovacs, op. cit. u bilj. 5, str. 318.

11 Za točno određenje roka vidi Henle, op. cit. u bilj. 5, str. 168.-169.

12 D. 18.2.2. Usp. i D. 41.4.2.4. Usp. npr.: Arangio-Ruiz, op. cit. u bilj. 1, str. 406.-410.; De Fontette, op. cit. u bilj. 5, str. 548.-551.; Petranović, op. cit. u bilj. 5, str. 1231.; Nicosia, op. cit. u bilj. 5, str. 30. i sl. Također glede sumnji na interpolacije ovog teksta u romanistici na prijelazu iz 19. u 20. st. usp. Henle, op. cit. u bilj. 5, str. 177.-179.

13 Usp. Arangio-Ruiz, op. cit. u bilj. 1, str. 405.; Zimmermann, op. cit. u bilj. 3, str. 736.; Nicosia, op. cit. u bilj. 5, str. 18. i sl.

14 Riječ je o širem pitanju koncepcije raskidnih uvjeta u rimskom pravu koji prema starijoj doktrini još nisu bili definirani kao posebna kategorija uvjeta. Pod condicio su se ponajprije podrazumijevali odgodni uvjeti, dok bi učinci raskidnih uvjeta bili ostvarivani u obliku sporazuma o raskidu pod odgodnim uvjetom. U novijoj doktrini već je rašireniji stav o postojanju raskidnih uvjeta kojima bi se priznavao stvarnopravni učinak. Općenito o problemu koncepcije uvjeta, njihovu stvarnopravnom učinku i mogućnosti ipso iure prestanka vlasništva kod in diem addictio i lex commissoria, s uputom na daljnju literaturu, usp. Sieg, op. cit. u bilj. 5, str. 25. i sl.; Henle, op. cit. u bilj. 5, str. 188.-192.; Arangio-Ruiz, op. cit. u bilj. 1, str. 420.-429.; De Fontette, op. cit. u bilj. 5, str. 554.-556.; Kaser, op. cit. u bilj. 1, str. 562.; Peters, op. cit. u bilj. 5, str. 164. i sl. (posebno analiza tekstova vezanih uz 
čina ugovaranja uglavka bitno je da bi odmah dolazilo do stjecanja posjeda i vlasništva stvari te plodova, a kupac bi istodobno snosio i rizik slučajne propasti stvari. ${ }^{15}$

U skladu s drugim stavom, o uvjetnoj kupnji, koji se veže uz Pomponija, odnosno u literaturi se njegovi počeci pripisuju Sabinu, pri sklapanju kupoprodaje uz in diem addictio ne bi odmah dolazilo ni do stjecanja posjeda, ni vlasništva, ni plodova, no kupac pod uvjetom ne bi odgovarao ni za slučajnu propast stvari. ${ }^{16} \mathrm{U}$ toj situaciji ugovor ne proizvodi pravne učinke odmah, već će kupoprodaja biti perfektna samo ako se do isteka dogovorenog roka ne pojavi bolji kupac.

Ne izabirući nijedno mišljenje kao isključivo valjano, Ulpijan je zaključio da je uglavak moguće koncipirati na oba načina te da samo o volji stranaka i načinu kako su postavile ugovor (quod actum est) ovisi kakve će on učinke imati, uvjetne ili bezuvjetne kupoprodaje. ${ }^{17}$ Oni se prvenstveno razlikuju, kako je već izraženo, za razdoblje od zaključenja ugovora i predaje stvari do isteka roka za davanje druge ponude, odnosno do prihvaćanja druge ponude, a temelje se na razlici stjecanja samo detencije kod uvjetne, odnosno posjeda i vlasništva kod bezuvjetne kupoprodaje (tj. kupoprodaje pod raskidnim uvjetom). ${ }^{18}$

Uz pitanje je li kupoprodaja bila uvjetna ili bezuvjetna posebna pozornost posvećena je problemu rizika slučajne propasti stvari (periculum rei venditae) ${ }^{19}$ Pri tome, Ulpijan je obradio i neke specifične slučajeve vezane za ovaj oblik ugovora. U D. 18.2.4.1 pošao je od Julijanova mišljenja o propasti koja ide na teret kupca te se osvrnuo na pitanje plodova koji su ostali nakon propasti prodane stvari. Jasno je da nakon propasti predmeta kupoprodaje nije moglo doći do aktivacije uvjeta i bolje ponude, no može se zamisliti da bi taj predmet mogao dati plodove koji bi mogli biti jednako vrijedni, a možda i vrjedniji, drugom kupcu koji je namjeravao dati ponudu za prodanu stvar koja je u međuvremenu propala. Na primjer, prodana krava koja se u razdoblju od sklapanja ugovora do roka ostvarenja uvjeta otelila, pri čemu bi tele prema redovnom sadržaju ugovora pripalo kupcu, no nakon toga, a prije isteka roka za novu ponudu, krava je uginula. U tom slučaju bi kupcima, i prvom i drugom, pod određenim okolnostima moglo biti važnije tele nego sama krava pa su mogli inzistirati na održanju, odnosno poboljšanju ponude iz prvog ugovora. Prema Julijanovu mišljenju, s obzirom na to da je predmet kupoproda-

in diem addictio str. 210.-223.); Flume, W., Die Aufhebungsabreden beim Kauf-lex commissoria, in diem addictio und sogenanntes pactum displicentiae - und die Bedingung nach der Lehre der römischen Klassiker, u: Medicus, D., Seiler, H. H., (ur.) Festschrift für Max Kaser zum 70. Geburtstag. Beck'sche Verlagsbuchhandlung, München, 1976., str. 319.-320.; Zimmermann, op. cit. u bilj. 3 , str. 732.; Ziliotto, P., Vendita con lex commissoira o in idem addictio: la portata dell'espressione res inempta, u: Garofalo, L., (ur.) Il ruolo della buona fede oggettiva nell'esperienza giuridica storica e contemporanea: atti del Convegno internazionale di studi in onore di Alberto Burdese, Vol. IV, CEDAM, Padova, 2003., str. 476.; Effer-Uhe, D. O., Die Wirkung der condicio im römischen Recht, Nomos, Baden-Baden, 2008., str. 126.-133.; Nicosia, op. cit. u bilj. 5, str. 1.-8., 28. i sl.

15 Iako su u romanistici 20. stoljeća izražena i disonantna razmišljanja prema kojima nije dolazilo do stjecanja vlasništva, već samo kvalificiranog posjeda, smatra se da je prevladao stav da je prvi kupac stjecao odmah i vlasništvo stvari. Usp. Zimmermann, op. cit. u bilj. 3, str. 734 .

16 D. 18.2.4pr. Usp. Pokecz Kovacs, op. cit. u bilj. 5, str. 328.-329. U ovom slučaju ne dolazi do prijelaza rizika na kupca, već se primjenjuje pravilo casum sentit dominus, za koje usp. Petrak, M., Traditio iuridica. Vol. I. Regulae iuris, Novi informator, Zagreb, 2010., str. 35.

17 Usp. Babusiaux, U., Id quod actum est. Zur Ermittlung des Parteiwillens im klassischen römischen Zivilprozess, Verlag C. H. Beck, München, 2006., str. 180.-181.; Nicosia, op. cit. u bilj. 5, str. 23.-26.

18 Thomas navodi da bi glavni razlog različitog shvaćanja i koncepcija in diem addictio bila činjenica posjedovanja i mogućnost dosjelosti. Također, prema istom autoru, predaja stvari bi mogla biti i glavni kriterij tumačenja volje stranaka kakve su učinke namjeravale dati uglavku. Usp. Thomas, op. cit. u bilj. 10, str. 568.-569.

19 Opširnije usp. Pennitz, M., Das Periculum rei venditae: ein Beitrag zum "aktionenrechtlichen Denken" im roemischen Privatrecht, Wien, Köln, Weimar, 2000. 
je bila plodonosna stvar koja je propala, a ne sam plod, jer je i on mogao biti zaseban predmet kupoprodaje kao buduća stvar, kupnja je postajala konačna te više nitko ne bi mogao dati bolju ponudu. ${ }^{20} \mathrm{U}$ D. 18.2.4.2, ako je predmetom jedne kupoprodaje bilo više stvari zajedno, a jedna od njih bi propala, bilo je moguće dati drugu ponudu te ako je ona u ukupnom iznosu bila viša od prvotne cijene, preostala stvar bi bila prodana drugom kupcu. ${ }^{21}$

U vezi s plodovima može se dodati da bi u slučaju prodaje stvari drugom kupcu prvi kupac trebao vratiti plodove koje je u međuvremenu ubrao prodavatelju, a ne predati ih drugom kupcu jer je druga kupnja nastajala neovisno o prvoj te je imala učinke tek od trenutka pristanka prodavatelja na drugu ponudu. ${ }^{22}$ Sva pravila o koristima i riziku slučajne propasti primjenjuju se na drugog kupca od trenutka nastanka drugog ugovora, a ne retroaktivno od trenutka sklapanja ugovora s prvim kupcem. U slučaju da je pak prvi kupac izjednačio ponudu, Ulpijan je u D. 18.2.6.1 postavio pitanje može li on zadržati plodove kao da nije bilo druge ponude ili ih treba vratiti kao da je došlo do novog ugovora. ${ }^{23}$ Pitanje je logično s obzirom na novo određenje cijene kao bitnog sastojka ugovora. U skladu s time i osnovni odgovor je bio da bi trebalo vratiti plodove, no ipak je dopušteno, s pozivom na Pomponija, da bi se mogla istražiti namjera stranaka te ostaviti plodove kupcu.

Analogno plodovima i njihovu vraćanju, može se postaviti i pitanje vraćanja plaćene cijene, odnosno je li ona plaćana odmah ili tek po proteku roka za davanje bolje ponude. Izvori o tome šute, dok je iznimka Papinijanov fragment D. 18.2.20, koji potvrđuje da su postojali slučajevi da se cijena plaćala odmah te da ju je trebalo vratiti ako bi ugovor bio zaključen s drugim ponuđačem. U konkretnom tekstu riječ je o prodavateljevoj delegatio drugom kupcu da dio cijene isplati prvom kupcu na ime onoga što je prvi kupac već ranije platio, odnosno da prvi kupac ne može izravno tužiti drugog kupca iz same kupoprodaje, već samo ako se drugi kupac obvezao izravno prvome na naknadu isplaćene cijene. ${ }^{24}$ Suvremenim rječnikom, riječ je o uputi (asignaciji) kojom se postizao brži povrat sredstava prvom kupcu te se on osiguravao da prodavatelj neće potrošiti u druge svrhe novac koji će dobiti od drugog kupca.

\subsection{BOLJA PONUDA}

Pravna sudbina ugovora o kupoprodaji, odnosno njegovi učinci, ovisila je o tome hoće li se pojaviti novi kupac i ponuditi nove uvjete kupnje koje će prodavatelj ocijeniti boljima. Pri tome, cijena, odnosno njezina visina, nije bila jedini kriterij pri odlučivanju koja je ponuda bolja. Prema Ulpijanu, koji se u tekstu D. 18.2.4.6 oslanja na Pomponijev stav, i bez elementa rastuće cijene bolja ponuda je postojala kada je predložena jednostavnija ili ranija isplata ili je

20 D. 18.2.4.1. Usp. Sieg, op. cit. u bilj. 5, str. 19.-20.; Peters, op. cit. u bilj. 5, str. 34.-35.

21 Navedeno proizlazi iz D. 18.2.4.2. Vidjeti i D. 18.2.17. Usp. Peters, op. cit. u bilj. 5, str. 35.; Nicosia, op. cit. u bilj. 5, str. 104.-109.

22 Za plodove vidi posebno D. 18.2.6; D. 18.2.14.4-5; D. 18.2.16. Usp. Ziliotto, op. cit. u bilj. 14, str. 491.-494., 501.; Pokecz Kovacs, op. cit. u bilj. 5, str. 330.-331. Također da je bio nužan prihvat ponude da bi nastupili učinci uglavka usp. Sieg, op. cit. u bilj. 5, str. 20.

23 Opširnije Lambrini, P., 'In diem addictio' e seconda compravendita tra le stesse parti: patto modificativo o 'nova emptio'?, u: Russo Ruggeri, C., (ur.) Studi in onore di Antonino Metro, vol. 3, Giuffrè, Milano, 2010., str. 383.-402. Usp. i Babusiaux, op. cit. u bilj. 17 , str. 187.

24 Uz D. 18.2.20. Usp. Peters, op. cit. u bilj. 5, str. 255.; Nicosia, op. cit. u bilj. 5, str. 113.-116.; Cannata, C. A., Su "in diem addictio" e "lex commissoria" (recenzija knjige E. Nicosia), Index, vol. 43, 2015., str. 340.-341. 
riječ o pogodnijem mjestu isplate za prodavatelja. ${ }^{25}$ Ponuda će se smatrati boljom i ako dolazi od pouzdanije osobe, a ne one u koju prodavatelj nema povjerenja jer ga je već iznevjerio u prijašnjim slučajevima ili pak u zajednici uživa takvu reputaciju. Također, ako je kupac dao jamca ili zalog ili ako od prodavatelja nije tražio da jamči za pravne ili materijalne nedostatke stvari, sve bi to činilo bolje uvjete kupnje. Općenito uzevši, sve što bi pridonosilo prodavateljevoj prednosti moglo bi se smatrati boljom ponudom. ${ }^{26}$

Poseban problem je tko i na koji način odlučuje je li i koja ponuda bolja, prethodna ili potonja. Odluka je prvenstveno u rukama prodavatelja, a ako on umre u međuvremenu, pravnici drže da je ključno postoji li osoba koja može dati svoj pristanak na bolju ponudu u roku za odluku. ${ }^{27}$ Ako taj rok prođe prije nego što nasljednik stekne nasljedstvo i bude u mogućnosti odlučiti o ponudi, prva kupnja će ostati na snazi. U slučaju da je nasljednik već stupio u pravne odnose ostavitelja prije isteka roka za davanje druge ponude te ona doista bude i predložena, on će biti u mogućnosti prihvatiti drugu ponudu kao što je to mogao i ostavitelj koji je sklopio ugovor.

Glede kriterija za odluku, smatramo da iz ukupnosti tekstova koji se odnose na ponudu proizlazi da je ona morala sadržavati određene elemente objektivnosti s obzirom na objašnjenja pravnika kada je ponuda bolja kao i na to da bi je prvi kupac mogao osporavati pred sudom ako je smatrao da druga ponuda doista nije bila bolja. ${ }^{28} \mathrm{U}$ vezi s tim je i zahtjev da je ponuda morala zaista postojati, tj. morala je biti istinita, a ne lažna. Podmetanje lažnog kupca (falsus emptor) i isticanje nepostojeće druge ponude bio je način na koji bi prodavatelj pokušao izbjeći nastanak i učinke ugovora s prvim kupcem, no ako je bio otkriven, prema Ulpijanu, D. 18.2.4.5, lažna ponuda ne bi bila priznata te bi situacija bila ista kao da nije ni dana "bolja" ponuda. ${ }^{29}$ Prva kupoprodaja bi tada bila priznata sa svim svojim učincima. Paulo je tome u D. 18.2.14pr. dodao i odgovornost za štetu. Naime, u slučaju da je prodavatelj prevario obojicu kupaca te je stvar prodao drugome po istoj ili nepovoljnijoj ponudi, ali oni toga nisu bili svjesni, prodavatelj je obojici bio odgovoran za štetu. ${ }^{30}$

Obrnuti problem je bio kada bi drugog kupca podmetnuo prvi kupac kako bi izbjegao kupnju. Tada se smatralo da je pristankom prodavatelja na drugu ponudu prestao prvi odnos, no prodavatelj je mogao tužiti prvog kupca za naknadu štete koju je pretrpio iz toga. ${ }^{31} \mathrm{U}$ zasebnoj skupini situacija kada je prodavatelj sam prihvatio drugu ponudu, a poslije bi se pokazalo da drugi kupac nije bio solventan ili je bila riječ o maloljetniku koji je sklopio ugovor bez pristanka tutora, prva kupoprodaja bi prestajala te je prodavatelj sam morao snositi štetu koja bi mu nastala zbog izbora drugog kupca koji bi se na kraju pokazao nepovoljniji. ${ }^{32}$

25 Usp. De Fontette, op. cit. u bilj. 5, str. 545.-546.; Pokecz Kovacs, op. cit. u bilj. 5, str. 319.-320.; Nicosia, op. cit. u bilj. 5, str. 41.-44.

26 Uz navedeno valja spomenuti i spor rimskih pravnika može li druga ponuda biti bolja ako bi i ugovor s kasnijim ponuditeljem bilo moguće sklopiti uz in diem addictio čime je prodavatelj mogao višestruko tražiti boljeg kupca i višu cijenu. Sabin je pri tome tvrdio da nije moguće dodati uglavak i drugoj prodaji, no Julijan je odgovorio potvrdno upućujući pri tome na dogovor stranaka kao odlučan. Usp. D. 18.2.11pr. Također za generalno pravilo vidi D. 18.2.5. Usp. Peters, op. cit. u bilj. 5, str. 41.-43.; Babusiaux, op. cit. u bilj. 17, str. 188.; Nicosia, op. cit. u bilj. 5, str. 41.-44.

D. 18.2.15pr. Usp. Sieg, op. cit. u bilj. 5, str. 7., 19.; Peters, op. cit. u bilj. 5, str. 47.

Usp. Sieg, op. cit. u bilj. 5, str. 16.-17.; Peters, op. cit. u bilj. 5, str. 26.-30. Za čisto subjektivnu procjenu usp. Petranović, op. cit. u bilj. 5, str. 1232.

Usp. Peters, op. cit. u bilj. 5, str. 33.-34.

Usp. Nicosia, op. cit. u bilj. 5, str. 98.-100.

D. 18.2.14.1. Usp. Ziliotto, op. cit. u bilj. 14, str. 492.-493., bilj. 21.

D. 18.2.14.2-3. Usp. Pokecz Kovacs, op. cit. u bilj. 5, str. 322.; Nicosia, op. cit. u bilj. 5, str. 66.-69. 
Nakon što je bila dana druga ponuda prodavatelj je bio dužan obavijestiti prvog kupca o njoj $^{33}$ te je održavanje ugovora na snazi ovisilo o prvom kupcu, odnosno on je mogao odlučiti hoće li poboljšati svoju ponudu i izjednačiti je s novom ili je još povećati te održati ugovor na snazi, ili se povući, odustati od ugovora te stvar prepustiti novom kupcu. ${ }^{34}$ Prema tome, prvi kupac je uvijek imao facultas alternativa koja mu je omogućavala da ponudi onoliko koliko nudi novi kupac i on je tada imao prednost.

Posebna situacija je bila kada prodavatelj nije htio pristati na drugu bolju ponudu. U tom slučaju, Sabin je odgovorio da mu je to bilo dopušteno te je prodavatelj tada ostajao pri prvoj prodaji, što je potvrdio i Ulpijan. ${ }^{35}$ No, trebalo je provjeriti je li navedeni uglavak možda utvrđen i u korist kupca. Ako je bilo tako, onda bi i prvi kupac mogao odustati od ugovora iako prodavatelj ne bi zaključio ugovor s kasnijim ponuđačem. Poseban je položaj bio založnog ili fiducijarnog vjerovnika kao prodavatelja jer je on morao prodati stvar boljem ponuđaču, ${ }^{36}$ osim ako je ta ponuda dana samo radi sprječavanja prodaje te tada ne bi bio odgovoran fiducijarnom dužniku za povredu povjerenja u odnosu. ${ }^{37}$

\subsection{ZAKLJUČNO O IN DIEM ADDICTIO U RIMSKOM PRAVU}

S obzirom na to da se kod uglavaka uz kupoprodaju često navodi u čiju se korist dodaju ugovoru, za uglavak o kupoprodaji uz pridržaj boljeg kupca može se reći da je bio prvenstveno sastavljen u korist prodavatelja jer je on ovim uglavkom bio osiguran da će stvar prodati za utvrđenu minimalnu cijenu, ali mu je bio dan i određeni rok u kojem bi mogao naći boljeg kupca. Opcija potrage ili čekanja drugog kupca pri tome je bila bez štetne posljedice koja bi se mogla očekivati u slučaju da prodavatelj nije u odgovarajućem roku odgovorio na kupčeve izjave, što bi bio odustanak prvog kupca. No, ugovor nije bio isključivo u rukama jedne ugovorne stranke, već se i kupcu, iako na suženiji način, ostavljala mogućnost da odluči o sudbini ugovora. On je naime, imao prioritetan položaj spram ostalih potencijalnih kupaca jer je i u slučaju pojave povoljnije ponude mogao poboljšati svoj prvotni prijedlog do razine nove ponude i u slučaju jednakih ponuda prodavatelj je morao stvar prodati prvom kupcu.

Glede vremenskog djelovanja, svrstavajući in diem addictio u uglavke sa stvarnopravnim učinkom, može se reći da domaća romanistika polazi od Julijanova stava za koji se smatra da mu je skloniji bio i Ulpijan, tj. polazi se od toga da su ugovor i svi njegovi učinci nastajali odmah te bi tako dolazilo i do prijenosa vlasništva ako je kupoprodaju slijedila predaja predmeta. Ako bi ugovor naknadno bio sklopljen s drugim boljim ponuđačem, uzimalo se kao da

33 D. 18.2.8. Usp. Nicosia, op. cit. u bilj. 5, str. 70.-72.

34 D. 18.2.7. Usp. Peters, op. cit. u bilj. 5, str. 47.

D. 18.2.9. Usp. Thomas, op. cit. u bilj. 10, str. 562.- 563.; Babusiaux, op. cit. u bilj. 17, str. 189.; Nicosia, op. cit. u bilj. 5, str. 53.-57.

36 D. 18.2.10. Usp. Noordraven, B., Die Fiduzia im römischen Recht, Gieben, Amsterdam, 1999, str. 258.; Nicosia, op. cit. u bilj. 5, str. 58. -60 .

37 Opširnije Karlović, T., Fiducia cum creditore u rimskom pravu, doktorska disertacija, Pravni fakultet Sveučilišta u Zagrebu, Zagreb, 2011., str. 230., i sl. 
stvar nije ni prodana (inempta) te bi prelazila odmah natrag u vlasništvo prodavatelja. ${ }^{38} \mathrm{Na}$ to upućuje i dužnost vraćanja plodova koje bi kupac valjano stekao za vrijeme trajanja ugovora.

\section{KUPOPRODAJNI UGOVOR UZ PRIDRŽAJ BOLJEG KUPCA U SUVREMENOM PRAVU}

\subsection{UGLAVAK O PRIDRŽAJU BOLJEG KUPCA U POREDBENOM PRAVU}

Recepcija rimskih pravila o kupoprodaji u srednjem vijeku te njihova pripadnost općem pravu (ius commune) utjecali su na djelomično održanje uglavka in diem addictio do današnjih dana, u kodificiranom ili nekodificiranom obliku. Naime, pregledom najvažnijih europskih kodifikacija građanskog prava nastalih u 19. stoljeću, koje su još na snazi, može se uočiti da je in diem addictio uređen kao poseban oblik kupoprodaje samo u austrijskom Općem građanskom zakoniku iz 1811. ${ }^{39}$ Mogućnost njegova ugovaranja postoji i u drugim kodifikacijama u općim odredbama obveznog prava ili pravilima o kupoprodaji, no zbog smanjene praktične važnosti uglavak je, može se reći, spušten na razinu običnih uvjeta s koje se i izdignuo u rimskom pravu.

Zbog veće dostupnosti sredstava komunikacije i mnogo bržih mogućnosti razmjene informacija, pa tako i u vezi sa sklapanjem ugovora o kupoprodaji, prodavatelju danas više nije nužno ugovarati poseban rok u kojem bi mogao konzultirati se s drugim ponuđačima ili čekati nove. Svakodobnom dostupnošću informacija na internetu, posebnim oglašivačkim stranicama te mogućnostima gotovo istodobnog javljanja s prihvatom ili protuponudom s bilo kojeg mjesta, osnovna svrha koja se ostvarivala dodavanjem in diem addictio - traženje najboljeg kupca, već je najvećim dijelom ispunjena. No, postoje konkretne situacije, poput paralelnih pregovora i čekanja odobrenja povezanih osoba, kao i slučaja nedostupnog ponuđača koji je preliminarno dao bolju ponudu, ali nije dostupan kada je dana druga ponuda, u kojima se ovaj uglavak može svrhovito upotrijebiti i danas, zbog čega smatramo korisnim dati poredbeni prikaz mogućnosti njegova ugovaranja i uređenja.

\subsubsection{FRANCUSKA}

Kronološkim redom nastanka velikih kodifikacija građanskog prava koje su u većoj mjeri definirale pravni krajolik Europe do danas prvi izvor je francuski Code civil iz 1804. godine (dalje: CC). ${ }^{40}$ On ne sadrži posebne odredbe o prodaji uz pridržaj boljeg kupca, a na temelju

38 Vidi D. 6.1.41pr., D. 18.2.4.3 i D. 20.6.3. Usp. De Fontette, op. cit. u bilj. 5, str. 555.-556.; Wesel, U., Zur dinglichen Wirkung der Rücktrittsvorbehalte des römischen Kaufs, Zeitschrift der Savigny-Stiftung für Rechtsgeschichte. Romanistische Abteilung, vol. 85, 1968., str. 123. i sl.; Peters, op. cit. u bilj. 5, str. 199.-233.; Nicosia, op. cit. u bilj. 5, str. 135.-151.

39 Allgemeines bürgerliches Gesetzbuch für die gesammten deutschen Erbländer der Oesterreichischen Monarchie, StF: JGS Nr. 946/1811, aktualizirano izdanje na dan 10. svibnja 2018., dostupno na: https://www.ris.bka.gv. at/GeltendeFassung. wxe? Abfrage=Bundesnormen\&Gesetzesnummer=10001622. 
komentara poznatog francuskog pravnika Pothiera koji je postavio teoretske temelje CC-a, ${ }^{41}$ glavni razlog bi bila rijetka primjena u praksi. ${ }^{42}$ Pothier je stoga pri prikazu in diem addictio i uputio na primjenu pravila o nazadkupnji koja se češće koristila i koja je stoga ušla kao zaseban oblik kupoprodaje u Code civil. Međutim, analizom izvornih odredaba o kupoprodaji iz 1804., kao i kasnijih izmjena u pogledu odgovarajuće materije, može se utvrditi da Code civil sadrži temelje za moguće ugovaranje in diem addictio.

U članku 1584. iz prvog odjeljka o kupoprodaji koji je ostao nepromijenjen do danas navodi se da kupoprodaja može biti sklopljena bezuvjetno, kao i pod uvjetom, odgodnim ili raskidnim, a glede njihova učinka primjenjuju se opće odredbe o uvjetima. ${ }^{43}$ No, u odredbama općeg dijela uočavaju se bitne razlike između prvotnog i aktualnog teksta Zakonika. U izvorniku su odgodni uvjeti bili uređeni člancima 1181. i 1182., a raskidni člancima 1183. i 1184. U tekstu koji je trenutačno na snazi, nakon velike reforme obveznog prava iz veljače 2016., ${ }^{44}$ pojam i glavne dvije vrste (odgodni i raskidni; ostale vrste uvjeta su ranije bile izričito navedene, ali su brisane izmjenama) uređeni su u čl. 1304., dok su učinci odgodnih uvjeta regulirani u čl. 1304.-6., a raskidnih u čl. 1304.-7. ${ }^{45}$

Učinak odgodnih uvjeta izmijenjen je novelom iz 2016. od izvorno retroaktivnog u neretroaktivni, tj. učinak uvjeta nastupa, ako nije drukčije ugovoreno, od trenutka ispunjenja. ${ }^{46}$ Kod raskidnih uvjeta situacija je drukčija. Prema prvotnom uređenju ispunjenje raskidnog uvjeta dovodilo je do opoziva obveze u smislu obvezivanja dužnika na povrat onoga što je primio. ${ }^{47}$ Izmjenama iz 2016. raskidni uvjeti su dobili izravan retroaktivni učinak, uz iznimke ako nije drukčije ugovoreno ili ako su obje stranke već ispunile svoje obveze što se primarno veže uz obveze s kontinuiranim ili povremenim činidbama. ${ }^{48}$ Ispunjenjem ili izjalovljenjem raskidnog uvjeta, ovisno kako je on bio postavljen, dolazi do prestanka ugovora i restitucije onoga

41 Usp. Stein, P., Rimsko pravo i Europa. Povijest jedne kulture, Golden marketing, Zagreb, 2007., str. 128.

42 Pothier, R.-J., CEuvres de Pothier. Tome troisième, Traites de contrats de vente et des retraits, Chanson, Paris, 1821., str. 277. Kod njegova slavnog prethodnika, Domata, također se može uočiti kod prikaza posebnih uglavaka uz kupoprodaju naglasak na nazadkupnji, dok je in diem addictio prvenstveno navođen pri objašnjenju raskidnih uvjeta. Usp. Domat, M., Les loix civiles dans leur ordre naturel, le droit public et legum delectus, Tome Premier, Durand, Paris, 1777., str. 28.-29., 35., 57.-58.

43 Art. 1584 CC.

44 Izmjena iz 2016. godine učinjena odredbom o izmjenama u obveznom pravu Ordonnance n 2016-131 du 10 février 2016 portant réforme du droit des contrats, du régime général et de la preuve des obligations.

45 Usp. Réforme du droit des obligations. Un supplément au Code civil 2016 à jour de l'ordonnance n 2016-131 du 10 février 2016, Dalloz, Paris, 2016., str. 36.-37.

46 Kako navode Latina i Chantepie kritike retroaktivnog djelovanja odgodnih uvjeta protežu se od početka 20. stoljeća te je u njima, prema autorima s pravom, napadnuto obrazloženje da je retroaktivno djelovanje bilo nužno radi zaštite interesa stranaka condicone pendente. Kako autori navode, sama činjenica da postoji ugovor dovoljna je za zaštitu interesa stranaka, koja je regulirana prema novom uređenju u čl. 1304.-5., dok je retroaktivnost djelovanja uvjeta morala ustupiti i pred načelom publiciteta javnih upisnika prava na nekretninama te pred ranijim stjecanjem posjeda pokretnina od strane trećih osoba za vrijeme pendencije. U samom obrazloženju nacrta izmjena Zakonika navodi se da je retroaktivnost "source de complexité" te da u stvarnosti nije imala učinke jer je dužnik (prodavatelj) stvarno djelovao kao vlasnik, a vjerovnik tek ovlaštenik uvjetnog prava. Također, kako je u nacrtu i predloženo, rizik slučajne propasti je bio na dužniku (prodavatelju). Usp. Réforme du droit des obligations, op. cit. u bilj. 45, str. 36.; Latina, M., Chantepie, G., La réforme du droit des obligations. Commentaire théorique et pratique dans l'ordre du Code civil, Dalloz, Paris, 2016., str. 674.-675.

48 Vidi čl. 1304.-7. CC-a. Usp. Réforme du droit des obligations, op. cit. u bilj. 45, str. 36.-37. Prema samim komentarima novih odredaba proizlazi da je stanje ostalo isto, odnosno da je i prije i poslije postojalo retroaktivno djelovanje raskidnih uvjeta. Usp. Latina, Chantepie, op. cit. u bilj. 46, str. 660. 
što je predano na osnovi ugovora prema odredbama čl. $1352 .{ }^{49}$ Što bi konkretno obuhvaćala ta restitucija, odnosno odnosi li se ona i na plodove, upitno je s obzirom na to da Zakon o tome ništa ne govori, za razliku od odgodnih uvjeta kod kojih je i u slučaju kada bi stranke ugovorile retroaktivno djelovanje uvjeta, prodavatelj zadržavao pravo na plodove do trenutka ispunjenja uvjeta. Kod raskidnih uvjeta bi se moglo tumačiti, prema šutnji zakonodavca (a contrario spram odgodnih uvjeta), da bi retroaktivnost obuhvaćala i plodove te bi ih kupac morao vratiti u skladu s čl. 1352.-3. Glede rizika slučajne propasti stvari, također nije ništa navedeno te je i ova situacija otvorena budućim raspravama i tumačenju kroz sudsku praksu. ${ }^{50}$

U oba slučaja, i odgodnog i raskidnog uvjeta, ne postoje nikakve zapreke za sklapanje ugovora o kupoprodaji uz pridržaj boljeg kupca. Ni čl. 1304.-2. (ranije čl. 1174.) koji proglašava ništetnom obvezu sklopljenu pod uvjetom čije bi ispunjenje bilo u isključivoj vlasti dužnika, u ovom slučaju ne bi bio primjenjiv. ${ }^{51}$ Konačno, s osloncem na odredbe o nazadkupnji (De la faculté de rachat, čl. 1659. - 1673.), i prema izvorniku i noveli iz 2009., 52 koje govore o opozivosti prijenosa vlasništva, može se izreći potvrdan stav o mogućem dodavanju in diem addictio kupoprodaji u francuskom pravu u oba oblika.

\subsubsection{AUSTRIJA}

Austrijski Opći građanski zakonik (dalje: OGZ) iz 1811. g., koji je dugo vremena bio na snazi i na područjima današnje Republike Hrvatske ${ }^{53}$ izričito je regulirao prodaju pod uvjetom boljeg kupca (Verkauf mit Vorbehalt eines besseren Käufers) u odredbama §§ 1083. - 1085. ${ }^{54}$ Pri tome je ova kupoprodaja oblikovana na dva načina - kao kupoprodaja pod odgodnim i pod raskidnim uvjetom - ovisno o tome je li predmet kupoprodaje predan kupcu ili ne. Iz toga proizlazi da su u OGZ-u preuzete obje koncepcije rimskog uglavka, prateći dvojbe rimskih klasičnih pravnika. Dvije mogućnosti također su prisutne kod odredaba o kupnji na probu

49 Prema obrazloženju Rapport au Président de la République uz Ordonnance n² 2016-131 du 10 février 2016 portant réforme du droit des contrats, du régime général et de la preuve des obligations podnesenom ispred Ministarstva pravosuđa, u dijelu koji se odnosi na Art. 1304-7, tako je navedeno "la rétroactivité en cas de réalisation de cette condition permettra donc une annulation des actes passés et des restitutions, pour retrouver la situation où se trouvaient les parties avant la conclusion de l'obligation." "“retroaktivnost će u slučaju ostvarenja uvjeta omogućiti poništenje izvršenih akata i restituciju, da bi se izvršio povrat u stanje u kojem su stranke bile prije zaključenja ugovora."). Usp. Réforme du droit des obligations, op. cit. u bilj. 45, str. 37. Također o restituciji usp. Klein, J., Les restitutions, Droit et patrimoine, no. 258, svibanj 2016., str. 90.-92.

$50 \mathrm{Uz}$ uputu i na suprotne stavove, prema Latini i Chantepieu i ovdje bi, kao kod odgodnih uvjeta, trebalo napraviti izuzetak od općeg pravila o retroaktivnom djelovanju uvjeta i prebaciti odgovornost na kupca. Usp. Latina, Chantepie, op. cit. u bilj. 46, str. 677.-679.

51 Usp. ibid., str. 663.

52 Usp. izmjenu izvršenu sa Loi n²009-526 du 12 mai 2009.

53 Glede konkretnih termina početka važenja OGZ-a na hrvatskim područjima (npr. u Istri od 1. listopada 1815., u Dalmaciji od 1. siječnja 1816., od 1. svibnja 1853. u Hrvatskoj i Slavoniji) vidi Vuković, M., Opći građanski zakonik: s novelama i ostalim naknadnim propisima, Školska knjiga, Zagreb, 1955., str. V. U vezi s prestankom i eventualnim suvremenim primjenama određenih dijelova OGZ-a nakon 1945., a s obzirom na Zakon o nevažnosti pravnih propisa donesenih prije 6. travnja 1941. godine i za vrijeme neprijateljske okupacije (Službeni list FNRJ, broj 86/1946) te Zakon o načinu primjene pravnih propisa donesenih prije 6 . travnja 1941. godine (Narodne novine, broj 71/1991), usp. Petrak, M., Rimsko pravo kao pozitivno pravo u Republici Hrvatskoj: prilog tumačenju Zakona o načinu primjene pravnih propisa donesenih prije 6. travnja 1941. godine, Hrvatska pravna revija, br. 6, 2006., str. 1.-11.

54 Usp. Gschnitzer, F., Schuldrecht. Besonderer Teil und Schadenersatz, Springer, Wien, 1963., str. 26.-27.; Mayer-Maly, T., $§ \$ 1080$ - 1089, u: Klang, H., Gschnitzer, F., (ur.) Kommentar zum Allgemeinen bürgerlichen Gesetzbuch, IV, 2, 2. izdanje, Österreichische Staatsdruckerei, Wien, 1978., str. 910.-913.; Apathy, P., §§ 1045 - 1089, u: Koziol, H.; Bydlinski, P.; Bollenberger, R., (ur.) Kurzkommentar zum ABGB, 2. izdanje, Springer, Wien, New York, 2007., str. 1192.-1193. 
koja izravno prethodi, a pri čemu se u sumnji kod ugovaranja toga uglavka predmnijeva da je kupnja na ogled sklopljena pod odgodnim uvjetom (§ 1080.).

Prema $\S 1083$. kada stvar nije predana prvom kupcu, perfekcija posla je odgođena do ispunjenja uvjeta. Nasuprot tome, u $\S 1084$., kada je stvar odmah predana kupcu, on bi stekao opozivo vlasništvo ((widerrufliches) Eigentum) ${ }^{55}$ jer je bilo predviđeno da će ugovor prestati odlukom o prodaji drugom kupcu. ${ }^{56}$ Zakonodavac je prema tome sam izveo zaključak o quod actum est iz činjenice predaje (Übergabe), ${ }^{57}$ a nije ga kao Ulpijan ostavljao slobodnoj prosudbi suca od slučaja do slučaja. S obzirom na redovitu primjenu termina Übergabe u OGZ-u u užem značenju traditio, tj. prijenos posjeda, kao modus stjecanja vlasništva pokretnina, i ovdje se pošlo od prijenosa posjeda, no ipak treba istaknuti da bi glede nekretnina Übergabe trebalo tumačiti u širem smislu prijenosa vlasništva te stoga i upisa u zemljišnu knjigu kao redovitog načina stjecanja vlasništva. ${ }^{58}$ Ako je na temelju ugovora izvršena uknjižba prava vlasništva, ugovor bi trebalo tumačiti da je sklopljen pod raskidnim, a ne suspenzivnim uvjetom jer je ionako upis bio nemoguć pod suspenzivnim uvjetom. ${ }^{59}$

Mogu li stranke ugovoriti drukčije, tj. da stvar bude prenesena, no da ugovor ipak bude pod odgodnim uvjetom, nije jasno definirano kroz posebnu alineju nijednog od dva članka. Naime, strogim tumačenjem iz njihove dikcije proizlazi da bi predaja stvari bila ključna za procjenu učinaka uglavka, bez obzira na možebitan drukčiji dogovor stranaka, što bi se moglo opravdati razlozima pravne sigurnosti. Apathy u komentaru OGZ-a uz navedeni članak navodi, međutim, suprotno, tj. da bi se zakonska norma o učincima uglavka primjenjivala tek u nedostatku drukčijeg sporazuma stranaka. ${ }^{60}$ Iako se drugi autori komentara ne izjašnjavaju u vezi s tim pitanjem, može se reći da bi Apathyjev stav bio više u skladu s dispozitivnošću obveznoga prava.

U vezi sa samim načinom prijenosa, može se istaknuti da je kod prodaje pokretnina uz raskidni uvjet dostatan bilo koji način prijenosa posjeda na temelju kojega bi se moglo steći vlasništvo, pa tako i prijenos posjedovnim konstitutom. Glede nekretnina bitno je da se takav uvjetni prijenos vlasništva može upisati u zemljišnu knjigu te onda ima učinak prema svima. ${ }^{61}$ To je važno zbog toga što bi iskorištavanjem prava izbora prodaje drugom kupcu, kao preobražajnog prava prodavatelja (Gestaltungsrecht), prestajao prvi ugovor te bi došlo i do automatskog povratka vlasništva. Prodavatelj tada može vlasničkom tužbom potraživati posjed stvari natrag i od prvoga kupca i svakoga trećeg koji ju je stekao od njega, a treći bi bio zaštićen samo

55 Usp. Binder, M., $\S \S 1083$ - 1085, u: Schwimann, M., (ur.) ABGB-Praxiskommentar, Vol. 5, 2. izdanje, Lexis Nexis, ORAC, Wien, 1997., str. 993.

56 Mayer-Maly je pri tome izrazio stav, suprotan dijelu ranijih autora, da je za odluku o ispunjenju uvjeta bilo dovoljno da je prodavatelj dobio neopozivu ponudu, a nije bilo nužno da je prihvati. Usp. Mayer-Maly, op. cit. u bilj. 54, str. 911.

57 Usp. Eccher, B., §§ 285 - 446, u: Koziol, H.; Bydlinski, P.; Bollenberger, R., (ur.) Kurzkommentar zum ABGB, 2. izdanje, Springer, Wien, New York, 2007., str. 388.-400.

58 Navedeno zaključujemo s osloncem na Mayer-Malya koji je pri usporedbi oblika tradicije potrebnih kod kupnje na ogled i kod in diem addictio naveo da je kod potonje kupoprodaje dostatan bilo koji oblik prijenosa posjeda jer je bitno stjecanje stvarnopravnog ovlaštenja, vlasništva, a ne samo određeni oblici koji služe isprobavanju stvari kao kod prve ("Es kommt ja nicht auf die tatsachliche Erprobungsmöglichkeit an, sondern auf die sachenrechtliche Verwirklichung."). Usp. Mayer-Maly, op. cit. u bilj. 54, str. 912.

59 Glede upisa u zemljišnu knjigu pod raskidnim uvjetom te nedopuštenosti suspenzivnog upisa usp. Iro, G., Bürgerliches Recht, Band IV: Sachenrecht, 4. izdanje, Springer, Wien, New York, 2010., str. 52.-53. (red. br. 3/22).

$60 \quad$ Usp. Apathy, op. cit. u bilj. 54, str. 1193.

61 Usp. Aicher, J., Kaufvertrag, u: Rummel, P., (ur.) Kommentar zum Allgemeinen Bürgerlichen Gesetzbuch, 1. Band, Manz, Wien, 1983., str. 1527. 
ako ograničenje uvjetom nije bilo upisano u zemljišnu knjigu zbog primjene načela povjerenja u potpunost $\mathrm{i}$ istinitost zemljišnih knjiga. ${ }^{62}$

Posebnost $\S 1084$. uređenje je situacije u kojoj ne bi bio izričito ugovoren rok u kojem se može javiti bolji kupac. Iako se očekuje da bi stranke uvijek ugovarale rok za iznošenje i prihvaćanje bolje ponude, pa se stoga može shvatiti odsutnost sličnog problema u rimskim izvorima, ipak se može dogoditi da rok ne bude preciziran. Tada bi se imala primijeniti odgovarajuća pravila o kupnji na ogled (pokus) koja kupcu daju primjeren rok (eine angemessene Frist, prema $\S 1082$.) za isprobavanje stvari.

Treća odredba ovog poglavlja ( $§ 1085$.$) opće je važnosti te se primjenjuje u oba slučaja,$ bez obzira na to kako je uglavak formiran. U njoj se početno navodi da odluku o boljoj ponudi donosi prodavatelj, uz otklon od rimskog in diem addictio u vidu mogućnosti prodavatelja da odbije povećanje cijene prvog kupca, čak i ako bi taj iznos bio viši od druge ponude. ${ }^{63}$ Iz teksta na prvi pogled proizlazi da prodavatelj može odbiti poboljšanu prvu ponudu neovisno o ukupnosti uvjeta, u smislu da mu se prvi kupac nije možda svidio te mu je bio spreman prodati stvar samo kao zadnju opciju, iako je moguće zapitati se je li ipak riječ o tome da cijena nije jedini kriterij za procjenu koja je ponuda bolja tako da jedna ponuda može biti i viša, ali su uvjeti generalno bolji u drugoj ponudi. ${ }^{64}$

U § 1085. zakonodavac je također propisao da će se kod ispunjenja uvjeta i povrata stvari prodavatelju od prvog kupca obračunati koristi koje je on imao od stvari te koristi prodavatelja od novca (kamate) koji je primio na ime cijene. Također, glede odgovornosti za poboljšanja i pogoršanja na stvari kupac ima položaj poštenog posjednika. To jasno proizlazi iz činjenice da je kod ispunjenja raskidnog uvjeta dolazilo do izravnog povrata vlasništva prodavatelju te bi on vlasničkom tužbom tražio povrat stvari dok bi kupac kao posjednik odgovarao za plodove i pogoršanja na stvari, odnosno imao pravo na naknadu troškova i poboljšanja. Jedino se uzima da kupac ne bi odgovarao za slučajnu propast stvari. ${ }^{65}$

\subsubsection{NJEMAČKA}

Analizom dostupnih materijala u vezi s nastankom njemačkog Građanskog zakonika (dalje: BGB) iz 1896. (1900. g. stupio na snagu $)^{66}$ može se uočiti da se in diem addictio kao posebno regulirani uglavak nalazio u prvom Nacrtu BGB-a iz 1888. godine. ${ }^{67}$ Riječ je o $\S 474$. prema kojem je prodavatelj pridržavao pravo da odustane od ugovora ako dobije bolju ponudu. ${ }^{68} \mathrm{U}$

62 Ibid., str. 1528.

63 Zbog navedenoga uvjet je definiran kao potestativan. Usp. Apathy, op. cit. u bilj. 54, str. 1193.

64 Usp. Mayer-Maly, op. cit. u bilj. 54, str. 913.; Aicher, op. cit. u bilj. 61, str. 1528.; Binder, op. cit. u bilj. 55, str. 993.

65 Usp. Apathy, op. cit. u bilj. 54, str. 1193.

66 Izdanje na snazi: Bürgerliches Gesetzbuch in der Fassung der Bekanntmachung vom 2. Januar 2002 (BGBl. I S. 42, 2909; 2003 I S. 738), das zuletzt durch Artikel 1 des Gesetzes vom 20. Juli 2017 (BGBl. I S. 2787) geändert worden ist. Dostupno na: https:// www.gesetze-im-internet.de/bgb/index.html, pristupljeno 10. svibnja 2018.

67 Usp. Entwurf eines bürgerlichen Gesetzbuches für das Deutsche Reich. Erste Lesung. Ausgearbeitet durch die von dem Bundesrathe berufene Kommission, Verlag von J. Guttentag, Berlin - Leipzig, 1888., str. 103.

68 Tekst $\S 477$. je glasio: "Hat der Verkäufer sich die Annahme des besseren Gebotes eines Dritten fur den Kaufgegenstand vorbehalten, so ist dadurch der Rücktritt von dem Vertrage fur den Fall als vorbehalten anzusehen, dass das bessere Kaufgebot eines Dritten erfolge und dieses Gebot von dem Verkäufer angennomen werde." 
Motivima uz prvi nacrt pri tome je pojašnjeno da se ovim tekstom željela razriješiti nedoumica u slučaju da iz ugovora ne bi bilo jasno je li u konkretnom slučaju ugovor sklopljen pod odgodnim ili raskidnim uvjetom ili uz pridržaj prava na odustanak od ugovora (Rücktritt), odnosno prava na jednostrani raskid ugovora. Izbor je pao na posljednju opciju koja je opisana kao primjerena i sasvim dostatna. ${ }^{69}$ Također je istaknuto da je za ostvarenje učinaka uglavka dovoljna primjena općih pravila o odustanku, tj. unaprijed osiguranom pravu na jednostrani raskid ugovora, a potrebno je posebno samo dogovoriti se o roku u kojem može biti dana bolja ponuda.

U Motivima je spomenuto pravo prvog kupca da poboljša svoju ponudu, a koje se na temelju pravila rimskog prava nalazilo i u pruskom Općem zemaljskom zakoniku i saskom Građanskom zakoniku, no smatralo se da ne postoje dovoljni razlozi za omogućavanje toga prava prvokupa. ${ }^{70}$ Kupac je bio zaštićen na drugi način - zahtjevom za objektivnim određenjem bolje ponude. Iako prodavatelj sam odlučuje o prihvatu druge ponude, u Motivima je navedeno da iz predloženog teksta proizlazi da druga ponuda mora biti objektivno bolja, pri čemu nisu potrebne nikakve daljnje specifikacije. ${ }^{71}$

Uz § 474., na pravo prodaje uz pridržaj boljeg kupca odnosio se i $§ 475$. u kojem je bilo predviđeno kada prestaje pravo na prodaju boljem kupcu. Paragraf je izražavao opće pravilo $§ 432$. Nacrta o prestanku prava na odustanak od ugovora ako je ono bilo vezano uz uvjet. Pri tome, ako rok za odustanak nije bio određen, uzimalo se da se od ugovora može odustati unutar tri mjeseca ako je riječ o kupoprodaji nekretnina, a u roku četiri tjedna za sve ostale stvari. ${ }^{72}$

U drugom Nacrtu, međutim, odustalo se od posebnog uređenja ovog uglavka te su prvotni $\S \S 474$. i 475 . brisani. ${ }^{73}$ Obrazloženje je bilo da su te odredbe uvrštene u prvi Nacrt uzimajući $\mathrm{u}$ obzir in diem addictio rimskog prava i pandektne znanosti u Njemačkoj 19. stoljeća, ${ }^{74}$ no da institut u pravnom prometu ima vrlo malu ulogu, odnosno gotovo se i ne pojavljuje u praksi. ${ }^{75}$ Također, dodano je da se njegova svrha dijelom može ostvariti ugovaranjem pridržaja prava na odustanak od ugovora (Vorbehalt des Rücktrittsrechts), na što je izričito uputila i Prva komisija. Komentar uz drugi razlog može se shvatiti i kao prigovor Druge komisije Prvoj zbog toga što prema prvom Nacrtu prvi kupac ne bi imao stvarnopravna ovlaštenja na stvari ni pravo izjednačenja bolje ponude kao što je imao u rimskom pravu pa je izgubljen smisao uglavka. ${ }^{76}$ Ispu- $^{-}$ štanjem bitnih karakteristika rimske kupoprodaje uz pridržaj boljeg kupca zasebno uređenje instituta prema prvom Nacrtu ne bi imalo svrhu jer su se učinci pridržaja mogli bez problema ostvariti drugim odredbama Zakonika, a potrebe prakse nisu zahtijevale dupliciranje pravila.

69 Usp. Motive zu dem Entwurfe eines Bürgerlichen Gesetzbuches für das Deutsche Reich, sadržane u: Mugdan, B., (ur.) Die gesammten Materialien zum Bürgerlichen Gesetzbuch für das Deutsche Reich, II. Band, R. v. Decker's Verlag, Berlin, 1899., str. 187.

73 U Drugom nacrtu, koji je s manjim izmjenama postao kasnije tekst BGB-a, tako je nakon kupnje na probu §§ 430.-432. slijedilo pravo nazadkupnje. Usp. Entwurf eines Bürgerlichen Gesetzbuchs für das Deutsche Reich. Zweite Lesung. Nach den Beschlüssen der Redaktionskommission, J. Guttentag, Verlagsbuchhandlung, Bände, Berlin, 1894., str. 134.

Glede pandektne znanosti i pandektnog prava, rimskog prava kao općeg prava njemačkih država, vidi više Stein, op. cit. u bilj. 41, str. 130.-137. gesammten Materialien zum Bürgerlichen Gesetzbuch für das Deutsche Reich, II. Band, R. v. Decker's Verlag, Berlin, 1899., str. 780. 
Kupoprodaja uz pridržaj boljeg kupca tako nije ušla u BGB, no i danas prema tekstu ovog Zakonika njezini učinci mogu se ostvariti primjenom pravila o pridržaju prava na odustanak od ugovora ( $\S$ 346. - 354.), o kupoprodaji uz ugovaranje prava nazadkupnje ( $\S \S 456$. - 462.), kao i općih pravila o uvjetima (§§ 158. - 163.). Prvu opciju, pridržaj prava na odustanak od ugovora, nije potrebno posebno objašnjavati. Bitno je ponoviti samo da se ovo pravo ostvaruje izjavom jedne strane drugoj, u dogovorenom ili primjerenom roku ako on nije utvrđen. ${ }^{77}$ Pri tome bi se pridržaj mogao bez problema uvjetovati pojavom boljeg kupca, no pridržaj prava raskida ima samo obveznopravni učinak te bi u slučaju otuđenja stvari od strane prvog kupca prodavatelj imao samo pravo na naknadu novčane protuvrijednosti (§ 346. II.). ${ }^{78}$

Kod prava nazadkupnje učinci kupoprodaje uz pridržaj boljeg kupca mogli bi se ostvariti bez ikakvog spominjanja boljeg kupca jer se ugovarao samo rok u kojem je prodavatelj mogao kupiti stvar natrag. Prodavatelj bi mogao ugovoriti rok za nazadkupnju za koji je smatrao da će biti dovoljan da potraži boljeg kupca te ako bi ga našao mogao je ostvariti pravo nazadkupnje. Riječ je o kompliciranijoj formi jer obuhvaća dva pravna posla, dok je kod primjene pravila o uvjetima ili pridržaju prava na odustanak od ugovora pod uvjetom riječ o jednom. Pri tome, najočitiji problem, iako rješiv, bilo bi da prodavatelj ostvari pravo nazadkupnje, no da se drugi kupac predomisli, pa da ostane bez ijednog kupca. Također valja primijetiti da izjavom prodavatelja o nazadkupnji nastaje obveznopravni zahtjev na povrat stvari (§ 457.). ${ }^{79}$

Kupoprodaji je moguće dodati i uvjet prema kojem će nastup učinaka ovisiti o pojavi boljeg kupca. Uvjet bi mogao biti koncipiran kao odgodni ili kao raskidni. Učinci odgodnog uvjeta kod kupoprodaje ponajprije su raspravljeni u vezi s pridržajem prava vlasništva dok cijena ne bude plaćena u cijelosti (Eigentumsvorbehalt, § 449.). ${ }^{80}$ Pri tome je uglavnom analiziran pravni položaj kupca. Položaj prodavatelja nije privukao veću pozornost, posebno jer ovim uvjetima Zakonikom nije dan povratni učinak. ${ }^{81} \mathrm{~S}$ te strane i pridržaj boljeg kupca kao odgodni uvjet ne bi povlačio veće probleme.

Situacija je drukčija kod raskidnih uvjeta. S obzirom na automatsko djelovanje raskidnih uvjeta prema $\S 158$. II., ${ }^{82}$ ako bi kupoprodaja bila sklopljena pod raskidnim uvjetom pojave boljeg kupca, postavlja se pitanje bi li on imao samo obveznopravni učinak ili bi ispunjenje uvjeta

77 S te strane je potvrđeno da je riječ o preobražajnom pravu (Gestaltungsrecht), a ne o zahtjevu. Usp. Kaiser, D., Rücktritt. Vorbemerkungen zu $§ 346$ ff, u: Löwisch, M., (red.) J. von Staudingers Kommentar zum Bürgerlichen Gesetzbuch mit Einführungsgesetz und Nebengesetzen, Zweites Buch, Recht der Schuldverhältnisse, $\$ \$ 158-328$ - 361, Sellier, de Gruyter, Berlin, 1995., str. 391.; Bork, R., Bedingung. Zeitbestimmung. Vorbemerkungen zu $\$ 158-163$, u: Habermann, N., (red.) J. von Staudingers Kommentar zum Bürgerlichen Gesetzbuch mit Einführungsgesetz und Nebengesetzen, Erstes Buch, Allgemeiner Teil, $§ \S 134$ - 163, Sellier, de Gruyter, Berlin, 1996., str. 618.; Westerman, P., § 158 BGB, u: Säcker, F. J. et al., (ur.) Münchener Kommentar zum Bürgerlichen Gesetzbuch, 7. izdanje, C. H. Beck, München, 2015., red. br. 57.

78 Situacija je ista sa slučajnom propasti stvari kod koje bi kupac morao vratiti novčanu protuvrijednost prodavatelju koji bi pak morao vratiti plaćenu cijenu. Usp. Harke, J. D., Allgemeines Schuldrecht, Springer, Berlin, Heidelberg, 2010., str. 111.-114.; Jaeger, T., Die Rechtsfolgen des Rücktritts vom Vertrag nach gesetzlichem Eigentumserwerb, Archiv für die civilistische Praxis, god. 215, br. 3-4, 2015., str. 535. i sl.

79 Usp. Harke, J. D., Besonderes Schuldrecht, Springer, Berlin, Heidelberg, 2011., str. 21.

80 Usp. Finkenauer, T., $\S \S 158$ - 163. Bedingung und Zeitbestimmung, u: Schmoeckel, M., Rückert, J., Zimmermann, R., (ur.) Historisch-kritischer Kommentar zum BGB, Bd. I, Allgemeiner Teil, $§ 1$ - 240, Mohr Siebeck, Tübingen, 2003., str. 895.-902. Vidi i Weber, H., Weber, J.-A., Kreditsicherungsrecht, Verlag C. H. Beck, München, 2006., str. 186. i sl.

81 Također i raskidni uvjeti imaju učinak ex nunc. Usp. Bork, op. cit. u bilj. 77, str. 641., 645.

82 Ovdje se navodi i razlika između prava na odustanak (jednostrani raskid ugovora) i raskidnog uvjeta s obzirom na to da je za odustanak potrebna izjava, dok je kod uvjeta za nastup učinaka dovoljno samo da se dogodi uvjetovana okolnost. Usp. Bork, op. cit. u bilj. 77, str. 643.; Westerman, op. cit. u bilj. 77, red. br. 44., 57. 
povlačilo i određene stvarnopravne posljedice. Kako je u njemačkom pravu primijenjeno načelo razdvajanja i apstrakcije prema kojemu je za prijenos vlasništva potreban uz obveznopravni ugovor još i realni ugovor o prijenosu vlasništva na koji se nadovezuje modus, način stjecanja, ispunjenje uvjetovane okolnosti i raskid kupoprodajnog ugovora ne bi imali izravan učinak na stjecanje vlasništva. Za nekretnine je dapače izričito navedeno da stvarnopravni ugovor, odnosno dopuštenje upisa prijenosa u zemljišne knjige (Auflassung), ne može biti sklopljen pod uvjetom i rokom te stoga ne bi mogli biti ostvareni takvi učinci (§ 925. II.). ${ }^{83}$ Dočim, ako bi realni ugovor kod prijenosa pokretnina (Einigung) bio sklopljen pod raskidnim uvjetom, a što bi se moglo izvesti i tumačenjem iz zajedničkog sklapanja ugovora o kupoprodaji i realnog ugovora, s obzirom na to da se na njega imaju primijeniti opća pravila o ugovorima, došlo bi i do prestanka vlasništva. ${ }^{84}$ Kao primjer za potonje navodi se prijenos vlasništva radi osiguranja (Sicherungsübereignung) kod kojega bi se to moglo izričito ugovoriti, iako ne bi proizlazilo iz samog ugovora o prijenosu vlasništva radi osiguranja. ${ }^{85}$ Jednako tome može se zamisliti da bi se isti učinak mogao dati i kupoprodaji pod raskidnim uvjetom pojavljivanja boljeg kupca.

U skladu sa svime navedenim može se jasno zaključiti da bi sklapanje ugovora o kupoprodaji uz pridržaj boljeg kupca bilo moguće prema njemačkom pravu, uvažavajući načelo dispozitivnosti, no ugovor i uglavak bi mogli imati samo obveznopravni učinak, osim u slučaju prodaje pokretnine uz koju bi i stvarnopravni ugovor trebalo uvjetovati istim uglavkom.

\subsection{KUPOPRODAJA UZ POGODBU O PRIDRŽAJU BOLJEG KUPCA U HRVATSKOM PRAVU}

U suvremenom hrvatskom pravu Zakon o obveznim odnosima iz 2005., prateći prethodni Zakon o obveznim odnosima iz 1978., ${ }^{86}$ ne sadrži u okviru dijela posvećenog kupoprodajama s posebnim pogodbama odjeljak ili odredbu o kupoprodaji uz pridržaj boljeg kupca. ${ }^{87}$ Iz toga proizlazi i odsutnost razrade problema ovog uglavka iz literature. Međutim, u skladu s načelom dispozitivnosti obveznoga prava ne postoje razlozi zbog kojih se ovaj uglavak ne bi mogao

83 Usp. Bork, op. cit. u bilj. 77, str. 625.; Schwab, K. H., Prütting, H., Sachenrecht, Verlag C. H. Beck, München, 2006., str. 138.; Westerman, op. cit. u bilj. 73, red. br. 25.

84 Pri tome se navodi da je kod uvjetnog prijenosa vlasništva pokretnina jasno vidljiva odijeljenost obveznopravnog i stvarnopravnog ugovora te prijenosa posjeda. Tako se uz kupoprodaju uz pridržaj prava vlasništva navodi da je ugovor o kupoprodaji bezuvjetan, a ugovor o prijenosu vlasništva da je uvjetan, dok sam prijenos posjeda ionako ne može biti uvjetan. Kod kupoprodaje uz pridržaj boljeg kupca, smatramo, uvjetni bi bili i ugovor o kupoprodaji i ugovor o prijenosu vlasništva. Usp. Schwab, Prütting, op. cit. u bilj. 79, str. 146. Također, glede stvarnopravnog učinka raskidnog uvjeta uz posao raspolaganja i prava na traženje posjeda stvari vlasničkom tužbom u skladu sa §985. BGB-a usp. Bork, op. cit. u bilj. 77, str. 646.

85 U tom smislu Schwab i Prütting: "Möglich ist auch, dass die Sicherungsübereignung nur bedingt erfolgt. Die auflösende Bedingung der Zahlung der Schuld lässt dann das Sicherungsübereignung automatisch an den früheren Eigentümer, den Schuldner zurückfallen." Usp. Bork, op. cit. u bilj. 77, str. 631.-632.; Finkenauer, op. cit. u bilj. 80, str. 913.-914.; Schwab, Prütting, op. cit. u bilj. 83, str. 163.

86 Zakon o obveznim odnosima, Službeni list, broj 29/1978, 39/1985, 57/1989; Narodne novine, broj 53/1991, 73/1991, 111/1993, 3/1994, 7/1996, 91/1996, 112/1999 i 88/2001.

87 Ovdje treba napomenuti da i jedan od uzora za pripremu Zakona o obveznim odnosima iz 1978., s posebnim utjecajem u području ugovornih odnosa, švicarski Obligationenrecht, također nema posebno reguliran navedeni uglavak. O područjima utjecaja švicarskog prava na pravila Zakona o obveznim odnosima (i starog i novog) opširnije u: Nikšić, S., Nekoliko napomena o nomotehničkom standardu Zakona o obveznim odnosima, u: Slakoper, Z., (ur.) Liber amicorum in honorem Vilim Gorenc, Pravni fakultet Sveučilišta u Rijeci, Rijeka, 2014., str. 188. i sl. 
pojaviti u praksi. Smatramo da bi ga stranke mogle bez problema dodati kupoprodajnom ugovoru, pri čemu bi sve detalje u vezi s posebnim pravima i obvezama trebale izričito ugovoriti. ${ }^{88}$

Pri odgovoru što i kako bi bilo dopušteno strankama ugovoriti te kako bi ugovor trebalo tumačiti kada bi stranke samo ugovorile prodaju pod uvjetom boljeg kupca, ali bez posebne razrade, najbliži odgovor daju odredbe o kupoprodaji s pridržajem prava vlasništva. Ovaj uglavak, kao sljednik lex commissoria i pactum reservati dominii, dijeli s kupoprodajom uz pridržaj boljeg kupca niz značajki, ponajprije uvjetovanosti ugovora i načina kako bi uvjet bio koncipiran. Prema čl. 462. st. 2. ZOO-a 2005. koji propisuje da bi se ugovor o kupoprodaji s pridržajem prava vlasništva u dvojbi trebao smatrati sklopljenim pod odgodnim uvjetom, može se zaključiti da je strankama dopušteno ugovor izričito sklopiti i pod odgodnim i pod raskidnim uvjetom. Ako je to moguće za uvjet o pridržaju prava vlasništva do isplate cijene u potpunosti, bilo bi i uz uvjet pridržaja boljeg kupca.

S osloncem na čl. 297. st. 2. i 3. ZOO-a 2005. koji uređuju pojam i učinak uvjeta, treba upozoriti da bi ispunjenje odgodnog uvjeta imalo retroaktivno djelovanje ("osim ako iz zakona, naravi posla ili volje strana ne proistječe što drugo”, st. 2.), dok ispunjenje raskidnog uvjeta ne bi imalo. ${ }^{89}$ Kod ugovora pod odgodnim uvjetom kada se u dogovorenom roku ne bi pojavio bolji kupac, kupoprodaja bi imala učinak od trenutka sklapanja ugovora s prvim kupcem. U razdoblju do ispunjenja uvjeta kupoprodaja nije imala redovite učinke. Iznimka bi jedino, uz opću odredbu o osiguranju uvjetnog prava iz čl. 299., moglo biti da bi se prvom kupcu, tumačenjem per analogiam s čl. 463. o kupoprodaji s pridržajem prava vlasništva, mogla pripisati odgovornosti za slučajnu propast ili oštećenje stvari od trenutka kada je stekao njezin posjed. Tada, kako stvar nije više mogla biti prodana drugom, boljem kupcu, trebalo bi uzeti da je ispunjen uvjet i da su nastupili učinci prve kupoprodaje te bi kupac morao platiti cijenu, slično onome kako je ranije objašnjeno u rimskom pravu.

Kod ispunjenja raskidnog uvjeta pojavom boljeg kupca, ugovor bi imao učinke do trenutka obavijesti prodavatelja o boljoj ponudi i raskidu ugovora prvom kupcu, kada bi oni prestali. Ponajprije, bila bi riječ o stvarnopravnim učincima, ${ }^{90}$ odnosno o prijenosu prava vlasništva, što je osnovno pitanje i kod kupoprodaje uz pridržaj prava vlasništva uz koje se veže i vrlo bitno ograničenje toga uglavka. Naime, prema dikciji čl. 462., krenuvši od “predaje stvari” u st. 1., a posebno prema st. 3. i 4. koji izričito govore samo o pokretnoj stvari, a što je izričito navedeno u literaturi, kupoprodaja uz pridržaj prava vlasništva ograničena je samo na pokretnine. ${ }^{91}$

88 Ugovorne stranke bi to mogle učiniti za pojedinačni ugovor, no postoji mogućnost da bi i jedna stranka mogla sama postaviti takvu odredbu u svojim općim uvjetima ugovora. Pitanje je bi li na taj način bila ugrožena svrha ugovora u skladu s čl. 296. st. 1. ZOO-a 2005. zbog moguće nesigurnosti za kupca u pogledu konačnog stjecanja stvari. Kod ugovora koji bi se odnosili na dražbe, smatramo da to ne bi bio slučaj, no glede drugih oblika sklapanja ugovora situacija je problematičnija. S obzirom na širinu teme uloge in idem addictio u postupku prodaje na dražbi, ovo pitanje je u postupku obrade u drugom radu.

89 Usp. Klarić, Vedriš, op. cit. u bilj. 2, str. 123.; Gorenc, V., (opća redakcija) Komentar Zakona o obveznim odnosima, Narodne novine, Zagreb, 2014., str. 467.

90 Usp. Vedriš, M., Opći dio građanskog prava, u: Goldštajn, A.; Barbić, J.; Vedriš, M.; Matić, Ž., Obvezno pravo, Prva knjiga, Informator, Zagreb, 1979., str. 332.-333.

91 Usp. Klarić, Vedriš, op. cit. u bilj. 2, str. 503. Ovdje se može primijetiti da je u njemačkom pravu pridržaj prava vlasništva također predviđen samo za pokretnine (§ 449. BGB-a). Usp. Weber, Weber, op. cit. u bilj. 80, str. 193.-194. 
Uvidom u literaturu iz stvarnog prava, uočava se, međutim, da ne postoji veći problem s prijenosom vlasništva pod uvjetom, bio on odgodan ili raskidan, i pokretnina i nekretnina. ${ }^{92}$ Pozivom na čl. 34. Zakona o vlasništvu i drugim stvarnim pravima (dalje u tekstu: ZV) ${ }^{93}$ navodi se da se vlasništvo može ograničiti uvjetom ili rokom, ${ }^{94}$ a ako je riječ o ograničenju vlasništva nekretnina ono djeluje prema trećima ako je upisano u zemljišnu knjigu. ${ }^{95}$ Također, izričito se navodi kao primjer ograničenja uvjetom prijenos uvjetovan isplatom cijene. ${ }^{96} \mathrm{Uz}$ to se navodi da bi odnos otuđivatelja i stjecatelja pod uvjetom bio prosuđivan kao odnos prethodnog i potonjeg vlasnika, s tim da bi otuđivatelj bio prethodni vlasnik ako je uvjet bio odgodni, a ako je bio raskidni onda bi stjecatelj bio prethodni vlasnik. ${ }^{97}$ Prema tome, uglavak o pridržaju boljeg kupca bi se mogao koncipirati kao odgodni i kao raskidni na svim stvarima.

Za konkretna prava i obveze stranaka kako su prikazana u rimskom pravu ne postoji konkretan oslonac u daljnjim odredbama ni ZOO-a 2005. ni ZV-a. Primjenjujući mjerila iz općih načela o postupanju u obveznim odnosima, kao i ograničenja koja ZOO 2005. nameće glede nedopuštenih odredaba i predmeta, može se reći da glede mogućeg ugovaranja prava prvoga kupca da izjednači ponudu, pozivom na primjer iz čl. 449. i pravo prvokupa, ne postoje zapreke. ${ }^{98} \mathrm{~S}$ druge strane, smatramo da prodavatelj ne bi smio biti ograničen samo na cijenu kao jedini kriterij bolje ponude, već bi mogao uzeti u obzir sve okolnosti ispunjenja obveze od strane prvoga, odnosno drugoga kupca.

Glede porabe stvari i ubiranja plodova u prvom redu bi stranke trebale same donijeti odluku o tome, no uzimajući u obzir opća pravila predviđena kod odgodnih uvjeta, kada se ne pojavi bolji kupac, prvi kupac bi stjecao sve plodove i koristi zbog retroaktivnog učinka uvjeta. Ako bi se pak pojavio bolji kupac, trebalo bi vratiti prodavatelju sve prihode prema pravilima o stjecanju bez osnove. Kod raskidnog uvjeta, kako on nema povratni učinak, koristi stečene tijekom trajanja odnosa trebale bi ostati prvom kupcu, osim ako bi drukčije bilo ugovoreno. ${ }^{99}$

92 Usp. Gavella, N. et al., Stvarno pravo, Informator, Zagreb, 1998, str. 324, 342. Također se može uputiti na općenitu Vedriševu tvrdnju još iz 1979. uz učinak raskidnih uvjeta: "U našem pravu ispunjenje raskidnog uvjeta ima stvarnopravni učinak. Međutim, ako je treći kao stjecalac bio pošten, tada se od njega ne može tražiti povrat radi zaštite načela poštenja i povjerenja u prometu." Usp. Vedriš, op. cit. u bilj. 90, str. 333.

93 Zakon o vlasništvu i drugim stvarnim pravima, Narodne novine, broj 91/1996, 68/1998, 137/1999, 22/2000, 73/2000, 129/2000, 114/2001, 79/2006, 141/2006, 146/2008, 38/2009, 153/2009, 143/2012 i 152/2014. Usp. Žuvela, M., Vlasničkopravni odnosi, 4. izdanje, Organizator, Zagreb, 2014., str. 110.-114.

94 Glede pokretnina usp. Gavella et al., op. cit. u bilj. 92, str. 324.-325.

95 Upis vlasništva ima učinak predbilježbe koja će biti opravdana ispunjenjem ili izjalovljenjem uvjeta. Usp. Gavella et al., op. cit. u bilj. 92, str. 342.; Josipović, T., Zemljišnoknjižno pravo, Informator, Zagreb, 2001., str. 158.-159.

96 Usp. Gavella et al., op. cit. u bilj. 92, str. 342.; Žuvela, op. cit. u bilj. 93, str. 111.

97 Posebno se može napomenuti da se brisanje upisa vlasništva stjecatelja koji je vlasništvo stekao pod uvjetom kada je uvjet ispunjen "provodi na temelju javne ili javnoovjerene isprave kojom se dokazuje da je ostvaren uvjet", odnosno brisanje uvjeta iz zemljišne knjige ako nije ispunjen uvjet provodi se isto tako "na temelju javne ili javnoovjerene isprave kojom se dokazuje da uvjet nije ispunjen”. Usp. Josipović, op. cit. u bilj. 95, str. 158.-159.

98 Glede uvjeta izjednačavanja ponude kod prava prvokupa vidi npr. Kačer, H., Perkušić, A., Pravo prvokupa i njegovo mjesto u hrvatskom (pozitivnom) pravu de lege lata $i$ de lege ferenda, Pravni vjesnik, god. 23, br. 3-4, 2007., str. 132.

99 Iako se to možda ne čini na prvi pogled tako, posebno u Viznerovim komentarima uz čl. 74. ZOO-a 1978. koji sadržajno odgovara čl. 297. ZOO-a 2005., koji je analizirao retroaktivnost kod odgodnih uvjeta kao zajedničko rješenje za obje vrste. Ipak, Vizner se, uz uputu na Vukovića, opredijelio za rješenje da bi stjecatelj pod raskidnim uvjetom trebao zadržati plodove jer je bio vlasnik stvari, osim ako bi bilo drukčije ugovoreno. Na Viznera kasnije upućuje i Cigoj. Usp. Vizner, B., Komentar zakona o obveznim (obligacionim) odnosima (knjiga I.), Zagreb, 1978., str. 347.; Cigoj, S., Komentar obligacijskih razmerij, I. knjiga, Ljubljana, 1984. str. 296. 
Iz svega navedenog može se zaključiti da bi uključenje in diem addictio kao posebnog uglavka uz kupoprodaju bilo moguće u suvremenom hrvatskom pravu. Stranke bi pri tome trebale izričito urediti međusobna prava i obveze, a u slučaju izostanka, uz opću primjenu pravila o kupoprodaji i uvjetima iz ZOO-a 2005., mogla bi se dopustiti i primjena §§ 1083. - 1085. Općeg građanskog zakonika kao pravnih pravila u skladu s odredbama Zakona o načinu primjene pravnih propisa donesenih prije 6. travnja 1941. godine. ${ }^{100} \mathrm{U}$ osnovi, pri tome ne bi nastala veća razlika jer se opća pravila o uvjetima kako su izložena i odgovarajuća pravila OGZ-a podudaraju.

\section{ZAKLJUČAK}

O značenju ugovora o kupoprodaji uz pridržaj boljeg kupca (in diem addictio) u rimskoj pravnoj praksi svjedoči izdvajanje tekstova koji se odnose na ovaj institut u Justinijanovim Digestama u poseban naslov (D. 18.2). Također, činjenica da je dobio posebno ime dostatno govori o njegovoj važnosti s obzirom na to da je samo manji dio uvjeta dobio zasebna imena, dok je većina ostala pod općim nazivom condicio. Osnovni problem, od kojega polaze rimski pravnici i s obzirom na koji su bili podijeljeni u dvije grupe, bio je kako shvatiti in diem addictio - kao kupoprodaju pod odgodnim ili pod raskidnim uvjetom. Kao što je vidljivo prema Ulpijanovu tekstu D. 18.2.2pr., pitanje nije konačno riješeno ni krajem klasičnog prava, a ni kod Justinijana s obzirom na preuzimanje teksta, već je strankama bilo dopušteno da uglavak i kupoprodaju oblikuju na bilo koji od dva načina. Ako to nisu izričito učinile, bilo je potrebno iz njihove volje i cjelokupnog postupka sklapanja ugovora tumačiti što su namjeravale.

Uz pitanje oblika, pred rimskim pravnicima učestalo se pojavljivao problem druge ponude, odnosno što bi bila bolja ponuda i kakav je bio položaj prvog kupca spram nje. Prema iznesenim rješenjima jasno je da bolja ponuda ne bi bila samo ona koja je sadržavala povećanje cijene, već i bilo koje drugo poboljšanje položaja prodavatelja, bilo faktične (pogodnije mjesto ili vrijeme ispunjenja) ili pravne naravi (umanjenje odgovornosti prodavatelja ili pojačanje obveznopravnog odnosa na strani kupca).

S obzirom na pripadnost in diem addictio institutu rimske kupoprodaje koja je bila jedan od važnijih predmeta recepcije rimskog prava u srednjem vijeku u Europi, ovaj uglavak preživio je i do vremena velikih kodifikacija. Međutim, do kraja 18. stoljeća njegova uloga u poslovnom prometu toliko je oslabjela, da su kreatori dvije od tri velike kodifikacije građanskog prava, u Francuskoj i u Njemačkoj, odlučili da nije potrebna njegova posebna regulacija. Jedino je u Austriji, u okviru OGZ-a, kupoprodaja uz pridržaj boljeg kupca posebno regulirana u $§ \S 1083$. - 1085. Zakonodavac je pri tome zadržao mogućnost oba oblika ugovaranja, i kupoprodaje pod raskidnim i pod odgodnim uvjetom, ovisno o tome je li predmet kupoprodaje prenesen ili ne.

U radu je također obrađena mogućnost ugovaranja uglavka u francuskom, njemačkom i, konačno, hrvatskom pravu primjenom pravila općih instituta obveznog prava. Odgovor je da bi se uglavak, u skladu s načelom dispozitivnosti obveznog prava, mogao ugovoriti u sva tri pravna sustava, i pod odgodnim i pod raskidnim uvjetom. Glede hrvatskog prava može se istaknuti da bi se, s obzirom na nepostojanje izričite norme koja bi upućivala na drugo, ku- 
poprodaja uz pridržaj boljeg kupca mogla ugovoriti i glede pokretnina i nekretnina, pri čemu bi kod potonjih radi osiguranja učinka prema trećima ograničenje uvjetom trebalo upisati u zemljišnu knjigu.

Smatramo da mogućnosti primjene in diem addictio u suvremenom pravu nisu zanemarive, a kako je upućeno i u romanističkoj literaturi njegova funkcija bi bila posebno važna u prodajama na dražbama. Kako je problem prodaje na dražbama aktualiziran novim oblicima elektroničke trgovine, tako se i danas sve više otvara polje primjene pravila o kupoprodaji uz pridržaj boljeg kupca zbog čega je moguć i intenzivniji interes za izravnim uređenjem ovoga instituta.

\section{LITERATURA}

1. Pascal, A. et al., (ur.) Code civil, 2017, 116 édition, Dalloz, Paris, 2017.

2. Aicher, J., Kaufvertrag, u: Rummel, P., (ur.) Kommentar zum Allgemeinen Bürgerlichen Gesetzbuch, 1. Band, Manz, Wien, 1983, str. 1526.-1528.

3. Apathy, P., $\S 1045$ - 1089, u: Koziol, H.; Bydlinski, P.; Bollenberger, R., (ur.) Kurzkommentar zum $A B G B$, 2. izdanje, Springer, Wien, New York, 2007., str. 1138.-1197.

4. Arangio-Ruiz, V., La compravendita in diritto romano, E. Jovene, Napoli, 1954.

5. Babusiaux, U., Id quod actum est. Zur Ermittlung des Parteiwillens im klassischen römischen Zivilprozess, Verlag C. H. Beck, München, 2006.

6. Binder, M., $\S \S 1083$ - 1085, u: Schwimann, M., (ur.) ABGB-Praxiskommentar, Vol. 5, 2. izdanje, Lexis Nexis, ORAC, Wien, 1997., str. 992.-994.

7. Bork, R., Bedingung. Zeitbestimmung. Vorbemerkungen zu $\S \S 158$ - 163, u: Habermann, N. (red.), J. von Staudingers Kommentar zum Bürgerlichen Gesetzbuch mit Einführungsgesetz und Nebengesetzen, Erstes Buch, Allgemeiner Teil, §§ 134 - 163, Sellier, de Gruyter, Berlin, 1996., str. 608.-669.

8. Burdese, A., Vendita (diritto romano), u: Azara, A., Eula, E., (ur.) Novissimo digesto italiano, Vol. XX, Unione tipografic - Editrice Torinese, Torino, 1975., str. 594.-600.

9. Cannata, C. A., Su "in diem addictio" e "lex commissoria" (recenzija knjige E. Nicosia), Index, vol. 43, 2015., str. 335.-352.

10. Cigoj, S., Komentar obligacijskih razmerij, I. knjiga, Ljubljana, 1984.

11. Daube, D., (ur.) Studies in the Roman Law of Sale. Dedicated to the memory of F. De Zulueta, Clarendon Press, Oxford, 1959.

12. De Fontette, F., Recherches sur l'in diem addictio, u: Studi in onore Pietro De Francisci, vol. III, Giuffrè, Milano, 1956., str. 539.-555.

13. De Zulueta, F., The Roman Law of Sale, Clarendon Press, Oxford, 1945.

14. Domat, M., Les loix civiles dans leur ordre naturel, le droit public et legum delectus, Tome Premier, Durand, Paris, 1777.

15. Eccher, B., $§ \S 285$ - 446, u: Koziol, H.; Bydlinski, P.; Bollenberger, R., (ur.) Kurzkommentar zum $A B G B$, 2. izdanje, Springer, Wien, New York, 2007., str. 256.-418.

16. Effer-Uhe, D. O., Die Wirkung der condicio im römischen Recht, Nomos, Baden-Baden, 2008.

17. Finkenauer, T., §§158 - 163. Bedingung und Zeitbestimmung, u: Schmoeckel, M.; Rückert, J.; Zimmermann, R., (ur.) Historisch-kritischer Kommentar zum BGB, Bd. I, Allgemeiner Teil, §§ 1 - 240, Mohr Siebeck, Tübingen, 2003., str. 881.-915. 
18. Flume, W., Die Aufhebungsabreden beim Kauf - lex commissoria, in diem addictio und sogenanntes pactum displicentiae - und die Bedingung nach der Lehre der römischen Klassiker, u: Medicus, D., Seiler, H. H., (ur.) Festschrift für Max Kaser zum 70. Geburtstag. Beck'sche Verlagsbuchhandlung, München, 1976., str. 309.-327.

19. Gavella, N. et al., Stvarno pravo, Informator, Zagreb, 1998.

20. Gorenc, V., (opća redakcija), Komentar Zakona o obveznim odnosima, Narodne novine, Zagreb, 2014.

21. Gschnitzer, F., Schuldrecht. Besonderer Teil und Schadenersatz, Springer, Wien, 1963.

22. Guarino, A., Diritto privato romano, 12. izdanje, Jovene, Napoli, 2001.

23. Harke, J. D., Allgemeines Schuldrecht, Springer, Berlin, Heidelberg, 2010.

24. Harke, J. D., Besonderes Schuldrecht, Springer, Berlin, Heidelberg, 2011.

25. Henle, R., Die rechtliche Natur der in diem addictio beim Kaufvertrage, u: Festschrift Paul Koschaker, II. Band., Böhlau, Weimar, str. 169.-192.

26. Horvat, M., Rimsko pravo, Pravni fakultet Sveučilišta u Zagrebu, 1998.

27. Huber, P., Comparative Sales Law, u: Reimann, M., Zimmermann, R., (ur.) The Oxford Handbook of Comparative Law, OUP, Oxford, 2006., str. 938.-966.

28. Iro, G., Bürgerliches Recht, Band IV: Sachenrecht, 4. izdanje, Springer, Wien, New York, 2010.

29. Jaeger, T., Die Rechtsfolgen des Rücktritts vom Vertrag nach gesetzlichem Eigentumserwerb, Archiv für die civilistische Praxis, god. 215, br. 3-4, 2015., str. 533.-580.

30. Josipović, T., Zemljišnoknjižno pravo, Informator, Zagreb, 2001.

31. Kačer, H., Perkušić, A., Pravo prvokupa i njegovo mjesto u hrvatskom (pozitivnom) pravu de lege lata $i$ de lege ferenda, Pravni vjesnik, god. 23, br. 3-4, 2007., str. 119.-153.

32. Kaiser, D., Rücktritt. Vorbemerkungen zu $\S 346$ ff, u: Löwisch, M., (red.) J. von Staudingers Kommentar zum Bürgerlichen Gesetzbuch mit Einführungsgesetz und Nebengesetzen, Zweites Buch, Recht der Schuldverhältnisse, §§ 158 - 328 - 361, Sellier, de Gruyter, Berlin, 1995., str. 384.-579.

33. Karlović, T., Fiducia cum creditore u rimskom pravu, doktorska disertacija, Pravni fakultet Sveučilišta u Zagrebu, Zagreb, 2011.

34. Kaser, M., Das römische Privatrecht, I, Das altrömische, das vorklassische und klassische Recht, 2. izdanje, Beck'sche Verlagsbuchhandlung, München, 1971.

35. Klarić, P., Vedriš, M., Građansko pravo, IX. izdanje, Narodne novine, Zagreb, 2006.

36. Klein, J., Les restitutions, Droit et patrimoine, no. 258, svibanj 2016., str. 90.-92.

37. Lambrini, P., 'In diem addictio' e seconda compravendita tra le stesse parti: patto modificativo o 'nova emptio'?, u: Russo Ruggeri, C., (ur.) Studi in onore di Antonino Metro, vol. 3, Giuffrè, Milano, 2010., str. 383.-402.

38. Latina, M., Chantepie, G., La réforme du droit des obligations. Commentaire théorique et pratique dans l'ordre du Code civil, Dalloz, Paris, 2016.

39. Mayer-Maly, T., $\S \S 1080$ - 1089, u: Klang, H., Gschnitzer, F., (ur.) Kommentar zum Allgemeinen bürgerlichen Gesetzbuch, IV, 2, 2. izdanje, Österreichische Staatsdruckerei, Wien, 1978., str. 899.-927.

40. Nicosia, E., In diem addictio e lex commissoria, Libreria Editrice Torre, Catania, 2013.

41. Nikšić, S., Nekoliko napomena o nomotehničkom standardu Zakona o obveznim odnosima, u: Slakoper, Z., (ur.) Liber amicorum in honorem Vilim Gorenc, Pravni fakultet Sveučilišta u Rijeci, Rijeka, 2014., str. 185.-201.

42. Noordraven, B., Die Fiduzia im römischen Recht, Gieben, Amsterdam, 1999.

43. Pennitz, M., Das Periculum rei venditae: ein Beitrag zum "aktionenrechtlichen Denken" im roemischen Privatrecht, Wien, Köln, Weimar, 2000. 
44. Peters, F., Die Rücktrittsvorbehalte des römischen Kaufrechts, Böhlau Verlag, Köln, Wien, 1973.

45. Petrak, M., Rimsko pravo kao pozitivno pravo u Republici Hrvatskoj: prilog tumačenju Zakona o načinu primjene pravnih propisa donesenih prije 6. travnja 1941. godine, Hrvatska pravna revija, br. 6, 2006., str. 1.-11.

46. Petrak, M., Traditio iuridica. Vol. I. Regulae iuris, Novi informator, Zagreb, 2010.

47. Petranović, A., Položaj kupca u pravnom režimu rimske kupoprodaje, doktorska disertacija, Zagreb, 1996.

48. Petranović, A., Uvjetovani konsenzus i rimska uvjetna kupoprodaja, Zbornik Pravnog fakulteta Sveučilišta u Rijeci, god. 28, br. 2, 2007., str. 1219.-1238.

49. Pokecz Kovacs, A., Advantages and Disadvantages by the in diem addictio, u: Sturm, F.; Thomas, P.; Otto, J.; Mori, H., (ur.) Liber Amicorum Guido Tsuno, Vico Verlag, Frankfurt am Main, 2013., str. 317.-334.

50. Pothier, R.-J., CEuvres de Pothier. Tome troisième, Traites de contrats de vente et des retraits, Chanson, Paris, 1821.

51. Romac, A., Rimsko pravo, Narodne novine, Zagreb, 1994.

52. Romano, S., Addictio in diem, u: Azara, A., Eula, E., (ur.) Novissimo Digesto Italiano, Vol. I, Unione Tipografico, Torino, 1957., str. 280.-281.

53. Schwab, K. H., Prütting, H., Sachenrecht, Verlag C. H. Beck, München, 2006.

54. Sieg, H., Quellenkritische Studien zur Bessergebotsklausel (in diem addictio) im römischen Kaufrecht, Friederichsen, de Gruyter \& Co. m.b.h., Hamburg, 1933.

55. Stein, P., Rimsko pravo i Europa. Povijest jedne kulture, Golden marketing, Zagreb, 2007.

56. Talamanca, M., Contributi allo studio delle vendite all'asta nel mondo classico, Atti Lincei, anno CCCLI., ser. VIII., vol. VI., fasc. 2., Roma, 1954.

57. Talamanca, M., Istituzioni di diritto romano, Giuffrè editore, Milano, 1990.

58. Thielmann, G., Die römische Privatauktion, zugleich ein Beitrag zum römischen Bankierrecht, Duncker \& Humblot, Berlin, 1961.

59. Thomas, J. A. C., Provisions for Calling Off a Sale, Tijdschrift voor Rechtsgeschiedenis, god. 35, br. 4, 1967., str. 557.-572.

60. Vedriš, M., Opći dio građanskog prava, u: Goldštajn, A.; Barbić, J.; Vedriš, M.; Matić, Ž., Obvezno pravo, Prva knjiga, Informator, Zagreb, 1979.

61. Vizner, B., Komentar zakona o obveznim (obligacionim) odnosima (knjiga I.), Zagreb, 1978.

62. Vuković, M., Opći građanski zakonik: s novelama i ostalim naknadnim propisima, Školska knjiga, Zagreb, 1955.

63. Weber, H., Weber, J.-A., Kreditsicherungsrecht, Verlag C. H. Beck, München, 2006.

64. Wesel, U., Zur dinglichen Wirkung der Rücktrittsvorbehalte des römischen Kaufs, Zeitschrift der Savigny-Stiftung für Rechtsgeschichte. Romanistische Abteilung, vol. 85, 1968., str. 94.-172.

65. Westerman, P., §158 BGB, u: Säcker, F. J. et al., (ur.) Münchener Kommentar zum Bürgerlichen Gesetzbuch, 7. izdanje, C. H. Beck, München, 2015. (dostupno na: https://beck-online.beck.de).

66. Ziliotto, P., Vendita con lex commissoira $o$ in idem addictio: la portata dell'espressione res inempta, u: Garofalo, L., (ur.) Il ruolo della buona fede oggettiva nell'esperienza giuridica storica e contemporanea: atti del Convegno internazionale di studi in onore di Alberto Burdese, Vol. IV, CEDAM, Padova, 2003., str. 475.-516.

67. Zimmermann, R., The Law of Obligations. Roman Foundations of the Civilian Tradition, Juta \& Co, Ltd., Kluwer, Deventer, Boston, Cambridge (MA), 1990.

68. Žuvela, M., Vlasničkopravni odnosi, 4. izdanje, Organizator, Zagreb, 2014. 


\section{IZVORI}

1. Allgemeines bürgerliches Gesetzbuch für die gesammten deutschen Erbländer der Oesterreichischen Monarchie, StF: JGS Nr. 946/1811, tekst na snazi na dan 10. svibnja 2018. (zadnje izmjene 7. prosinca 2017.), https://www.ris.bka.gv.at/GeltendeFassung.wxe?Abfrage=Bundesnormen\&Gesetzesnummer=10001622.

2. Bürgerliches Gesetzbuch in der Fassung der Bekanntmachung vom 2. Januar 2002 (BGBl. I S. 42, 2909; 2003 I S. 738), das zuletzt durch Artikel 1 des Gesetzes vom 20. Juli 2017 (BGBl. I S. 2787) geändert worden ist; https://www.gesetze-im-internet.de/bgb/index.html.

3. Code civil, tekst na snazi na dan 10. svibnja 2018. (zadnje izmjene 3. siječnja 2018.), https://www. legifrance.gouv.fr/affichCode.do?cidTexte=LEGITEXT000006070721.

4. Entwurf eines bürgerlichen Gesetzbuches für das Deutsche Reich. Erste Lesung. Ausgearbeitet durch die von dem Bundesrathe berufene Kommission, Verlag von J. Guttentag, Berlin - Leipzig, 1888.

5. Entwurf eines Bürgerlichen Gesetzbuchs für das Deutsche Reich. Zweite Lesung. Nach den Beschlüssen der Redaktionskommission, J. Guttentag, Verlagsbuchhandlung, Bände, Berlin, 1894.

6. Loi n²009-526 du 12 mai 2009.

7. Motive zu dem Entwurfe eines Bürgerlichen Gesetzbuches für das Deutsche Reich, u: Mugdan, B., (ur.) Die gesammten Materialien zum Bürgerlichen Gesetzbuch für das Deutsche Reich, II. Band, R. v. Decker's Verlag, Berlin, 1899.

8. Ordonnance $\mathrm{n}^{\circ}$ 2016-131 du 10 février 2016 portant réforme du droit des contrats, du régime général et de la preuve des obligations.

9. Protokolle der Kommission für die zweite Lesung des Entwurfs des Bürgerlichen Gesetzbuchs, u: Mugdan, B., (ur.) Die gesammten Materialien zum Bürgerlichen Gesetzbuch für das Deutsche Reich, II. Band, R. v. Decker's Verlag, Berlin, 1899.

10. Rapport au Président de la République uz Ordonnance $n^{\circ}$ 2016-131 du 10 février 2016 portant réforme du droit des contrats, du régime général et de la preuve des obligations.

11. Réforme du droit des obligations. Un supplément au Code civil 2016 à jour de l'ordonnance n 2016-131 du 10 février 2016, Dalloz, Paris, 2016.

12. Zakon o načinu primjene pravnih propisa donesenih prije 6. travnja 1941. godine, Narodne novine, broj 73/1991.

13. Zakon o obveznim odnosima, Narodne novine, broj 35/2005, 41/2008, 125/2011 i 78/2015.

14. Zakon o obveznim odnosima, Službeni list, broj 29/1978, 39/1985, 57/1989, Narodne novine, broj 53/1991, 73/1991, 111/1993, 3/1994, 7/1996, 91/1996, 112/1999 i 88/2001.

15. Zakon o načinu primjene pravnih propisa donesenih prije 6. travnja 1941. godine, Narodne novine, broj 71/1991.

16. Zakon o nevažnosti pravnih propisa donesenih prije 6. travnja 1941. godine i za vrijeme neprijateljske okupacije, Službeni list FNRJ, broj 86/1946.

17. Zakon o vlasništvu i drugim stvarnim pravima, Narodne novine, broj 91/1996, 68/1998, 137/1999, 22/2000, 73/2000, 129/2000, 114/2001, 79/2006, 141/2006, 146/2008, 38/2009, 153/2009, $143 / 2012$ i $152 / 2014$. 
Tomislav Karlovic**

Ivona Rapic**

\section{IN DIEM ADDICTIO IN ROMAN LEGAL TRADITION}

\section{Summary}

The paper analyses in diem addictio, a provision for calling-off a sale in case that the seller will not receive and accept a better offer within a given time in Roman law. It is elaborated on a number of issues pertinent to in diem addictio, especially to the issue what constitutes a "better offer" and what obligations arise for the parties when the better offer is given. The second part of the paper discusses the possibility of including this provision in contemporary law of sales, specifically in selected legal systems - French, Austrian, German and Croatian law. It is concluded that, in addition to specific regulation of this provision in Austrian ABGB, other legal systems as well provide suitable and sufficient basis for the addition of this provision to the contract of sale, both in the form of suspensive and resolutive condition.

Keywords: $\quad$ Contract of sale, emptio venditio, in diem addictio, provision for calling-off a sale in case that the seller will not receive and accept a better offer within a given time, Roman law 